\title{
A taxonomic review of the Norwegian species of Raphitoma (Gastropoda: Conoidea: Raphitomidae)
}

\author{
Tore Høisæter'
}

Høisæter T. 2016. A taxonomic review of the Norwegian species of Raphitoma (Gastropoda: Conoidea: Raphitomidae). Fauna norvegica 36: 9-32.

The problematic conoidean genus Raphitoma s.l. in inshore Norwegian waters is revised based on fresh material from all along the coast of Norway. This largely shallow water group is represented by at least six species in Norwegian waters of which two, Raphitoma obesa n.sp. and R. maculosa $\mathrm{n}$.sp. are described as new, and another Raphitoma aequalis (Jeffreys, 1867) is reported from Norway for the first time. The taxonomic and nomenclatural status of $R$. reticulata (sensu Jeffreys 1867) and $R$. asperrima (sensu Forbes \& Hanley 1853) are discussed. Empty shells of several additional species indicate that the number of Raphitoma-species living in the North East Atlantic will be further increased in the future. The morphological variability of each species is described if possible. Shell morphology, including microsculpture and protoconch details as deduced from LM photographs, are used for distinguishing the species. Some easily observable behaviour and soft part morphology features were found to be promising areas for further studies.

doi: 10.5324/fn.v36i0.1839. Received: 2015-02-19. Accepted: 2015-12-22. Published online: 2016-02-24. ISSN: 1502-4873 (printed), 1891-5396 (electronic).

http://zoobank.org/8520BB86-9308-4775-A570-5F4FD64C68EB

Keywords: distribution, Norwegian inshore waters, North Sea, morphology, taxonomic characters, new species

1. Department of Biology University of Bergen P.O. Box 7800 N-5020 Bergen Norway

Corresponding author: Tore Høisæter

http://www.zoobank.org/Authors/8701A4E7-5BD0-4E70-8F68-ED4E51936B2F

E-mail:tore.hoisater@bio.uib.no

\section{INTRODUCTION}

Recently the troublesome taxonomy of Conoidea has been put on a firmer basis based mainly on extensive new material from the tropical western Pacific. This has led to both a detailed molecular phylogeny of the entire superfamily (Puillandre et al. 2008, 2011, Bouchet et al. 2011) and to several generic revisions (e.g. Olivera et al. 2008, Puillandre et al. 2009, 2010, Morassi \& Bonfitto 2010, Fedosov 2011). One of the outcomes of this work has been that the artificial 'family' Turridae (sensu Powell 1966) is split into 13 monophyletic families of which the Raphitomidae is the largest and most diverse. Species from the North-East Atlantic have only sporadically been included in these revisions, regrettably, as some of the name bearing types within this megadiverse group are from this region.

The North-East Atlantic deep-water conoidean species were revised by Bouchet \& Warén (1980) but no corresponding revision of the inshore species in Norwegian waters has been done. The numerous Mediterranean species are under revision by Pusateri et al. $(2012,2013)$, and so far four species of Raphitoma have been described. The present review is an attempt at a morphologically based description of the known Norwegian species of Raphitoma as traditionally understood. With the exception of two species, Raphitoma reported from Norwegian coastal waters are rare, and little material is available for a critical review.

Thirty two species of Raphitoma are listed as European in CLEMAM (2015). Two recent check lists from the Mediterranean mention 14 species from Malta (Cachia et al. 2001) and 14 from Italian waters (Spada 2008). Ten of the species are common to the two lists. Some of the species 
considered valid in CLEMAM or Spada (2008) are regarded as synonyms in Cachia et al. (2001) and vice versa. The recently started revision of the Mediterranean species of the group by Pusateri et al. $(2012,2013)$ indicates that at least 21 species, of which four are undescribed, are living in the Mediterranean. The check list by Cachia et al. (2001) contains brief descriptions and sketchy drawings of each species and seems at present, together with the so far incomplete revision of Pusateri et al. $(2012,2013)$, to be the best guide to the Mediterranean members of the group. Four of the North-European species are treated in the well-known series by Fretter \& Graham (1985) and Graham (1988), while useful drawings of the same four species are presented in Hubendick \& Warén (1976).

During a comprehensive survey of the distribution of shell bearing gastropods along the Norwegian coast (Høisæter 2009), several difficulties were encountered in identifying specimens of Raphitoma s.l. by use of standard identification guides (e.g. Graham 1988). These problems were mainly due to large variability in shell characters and apparent overlap in morphology between closely related species. Since then, more material has become available, permitting a detailed description of several Norwegian species from both living specimens and shells with intact colour pattern and protoconchs. By combining behaviour with macro-morphological and micro-morphological shell characters, I conclude that at least six species, of which two are described as new, are found in Norwegian waters. The Norwegian species of the group are compared with the British species, especially as described in Jeffreys (1867). To my knowledge this work by Jeffreys is the most recent revision of the group from the North-Eastern Atlantic. Some of my results have been suggested before but not based on such diverse material and never properly discussed in the scientific literature.

\section{MATERIAL AND METHODS}

This revision covers roughly the same region as defined in Høisæter (2009), i.e. the Norwegian inshore waters and shelf, but excluding the North Sea and the western 'slope' of the Norwegian Trench. A total of some 210 specimens and c. 220 empty shells of Raphitoma collected by the author around the Norwegian coast from $60^{\circ}$ to $71^{\circ} \mathrm{N}$ between 1967 and 2008 (see Høisæter 2009) and c. 140 specimens from Nordland $\left(67^{\circ}\right.$ to $\left.68^{\circ} \mathrm{N}\right)$ and 145 from Skagerrak $\left(58^{\circ}\right.$ to $\left.59^{\circ} \mathrm{N}\right)$ collected and sorted by Per Bie Wikander, were available for study of morphological characters. A few valuable specimens donated by David Osca and Per Johannessen from the Norwegian west coast and the North Sea are included as well. In addition 35 lots of older material from the University Museum of Bergen Natural History Collections (ZMBN) have been studied. A photograph of the holotype of Defrancia purpurea var. oblonga Jeffreys, 1867 has been provided by USNM (United States National Museum Washington DC). Other abbreviations used in the text: BMNH (Museum of Natural History London); S.D. (Subsequent Designation); W/L (width to length ratio).

The characters found to be most useful are: Macrosculpture (Figure 1) microsculpture (Figure 2) protoconch (Figure 3) colour pattern and sometimes, relative length of the siphonal canal. The study of conchological characters was supplemented by a few observations of crawling animals. Descriptions of shell morphology and living animals are based on photographs taken under a stereo microscope with an Olympus 4.1 Mpix. digital camera and processed in Adobe Photoshop ${ }^{\mathrm{TM}}$. All photographs (except those copied from published articles as specified in the figure captions) were taken and processed by the author. All material is deposited at ZMBN.

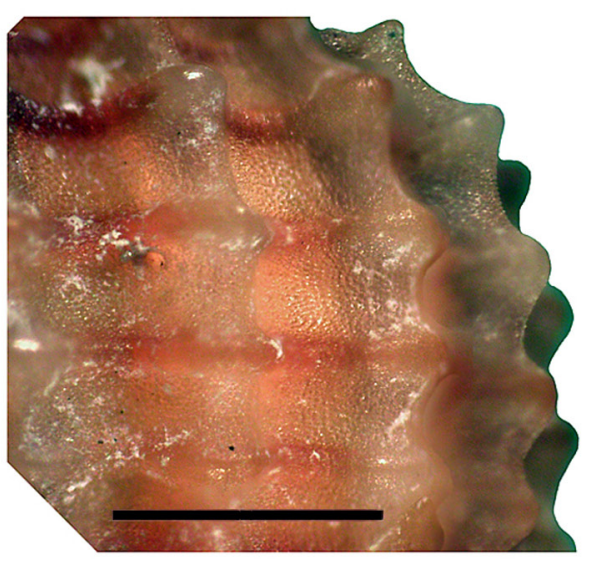

A

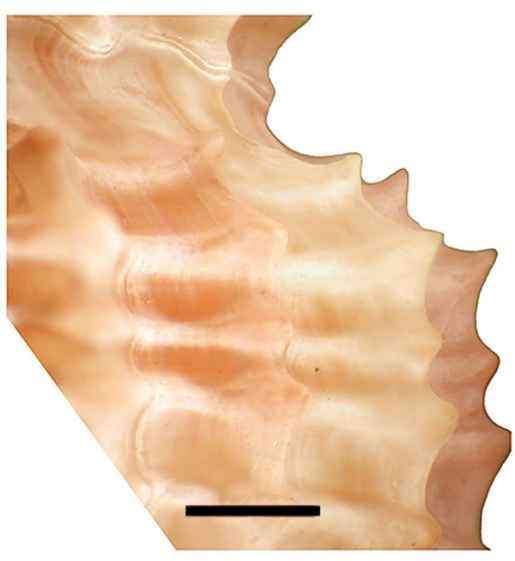

B

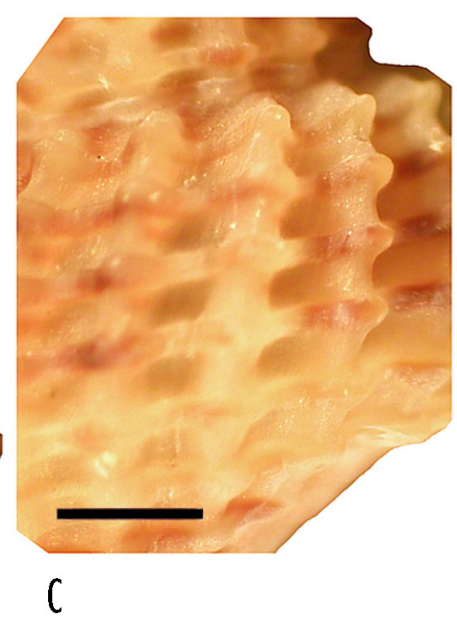

C

Figure I. Raphitoma spp., sculptural details. A. R. linearis $(4.9 \mathrm{~mm})$; B. R. cf. echinata $(11.1 \mathrm{~mm})$; C. R. maculosa $\mathrm{n} . \mathrm{sp} .(7.2 \mathrm{~mm})$. Scale bars $=500 \mu \mathrm{m}$. 
2.
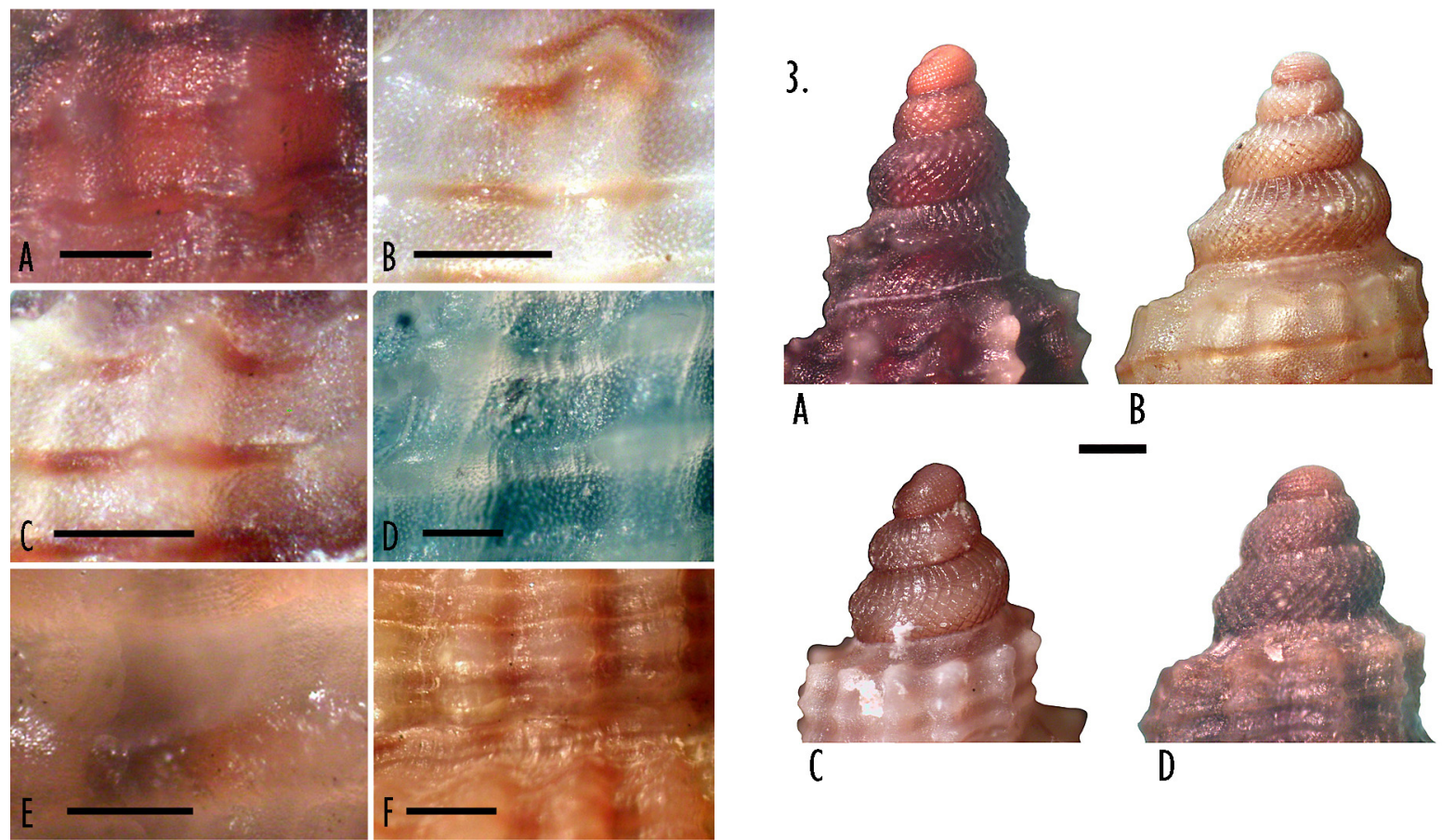

Figure 2. Details of microsculpture of six specimens of Raphitoma. A. R. linearis; B and C. R. aequalis; D. R. obesa n.sp.; E. R. maculosa n.sp.; and F. $R$. concinna. Scale bars $=200 \mu \mathrm{m}$, except $\mathrm{F}=500 \mu \mathrm{m}$.

Figure 3. Raphitoma spp, protoconchs. A. R. linearis; B. R. aequalis; C. R. maculosa n.sp. D. R. concinna. Scale bar $=200 \mu \mathrm{m}$.

\section{RESULTS}

\section{Conchological characters}

The macrosculpture consists of strong axial ribs crossed by spiral cords. Where these two structural elements cross each other, nodes of varying strength are created. The extremes are drawn out into pointed spikes (Figure 1B) and, at the other extreme, in modest swellings on the ribs (Figure 2F). Most species have nodes of intermediate strength (Figures 1A and C). I did not find it worth while to measure the relative length of the siphonal canal as it is usually both variable and hard to measure, e.g. Figures 11 and 23 (although rather constant for some taxa, see Figure 6). The microsculpture turned out to be rather specific for each taxon varying from a smooth silky surface (Figure 1B), a surface densely covered with tiny pustules (Figures 2B - D) to a rough, slightly wrinkled surface (Figure 2F). Shell colour pattern may be a useful character in some species, but in other species it is variable, and is anyway fading fast when the snail dies or is stored in ethanol.

All Norwegian species of the genus have protoconchs with an apical whorl with ten to twelve dense spirals followed by two to three whorls with the characteristic 'raphitomine' decussate sculpture. The number of protoconch whorls ranges from four (Figure 3A) to a little more than three (Figure 3C, D). In some species the protoconch ends in a keel (Figures $3 \mathrm{~A}, \mathrm{~B})$. The apical angle varies from c. $42^{\circ}$ (Raphitoma linearis, Figure 3A) to c. $54^{\circ}$ ( $R$. aequalis and $R$. concinna, Figures 3B, D). The diameter of the apical whorl is sometimes a useful taxonomic character (cf. Figure 3B with 3D) as is the W/L ratio of the protoconch (Figure 3D shows a protoconch wider than high, as opposed to the three others in Figure 3).

\section{TAXONOMY}

\section{Conoidea Fleming, 1822}

\section{Raphitomidae Bellardi, 1875}

(Type genus Raphitoma Bellardi, 1847)

Daphnellinae Casey, 1904

Pleurotomellinae F. Nordsieck, 1968

Taraninae Casey, 1904

Tatcheriidae Powell, 1942

In reviewing a taxon of organisms, two types of problems must be confronted, the identification and descriptions of the boundaries between different members of the taxon, and determination of the correct names of these members, on every taxonomic level. Both of these are highly relevant for the group under study here. The intraspecific variability within many of the species makes it hard to definitely delimit the species (identify species boundaries). Neither the names 
of the family, names of the genus or genera included, nor the names of individual species found in Norwegian waters, are satisfactorily resolved. I follow Bouchet et al. (2011) in elevating 'Raphitominae' to full family status, and also largely accept their scope of the group.

According to the diagnosis of Bouchet et al. (2011) members of this family are variable both in shape and size, sculpture variously developed, but most typically with well-developed spiral and axial elements. Anal sinus either subsutural, shaped as a 'reversed L', or on subsutural ramp, very shallow to rather deep. The protoconch either multispiral planktotrophic (the majority), or paucispiral. The multispiral protoconch with spirally striated protoconch I and protoconch II with diagonally cancellated sculpture. No operculum. Radula of hypodermic marginal teeth of very variable size and morphology. Radula apparatus sometimes reduced or lacking completely.

Remarks. Until recently this taxon has been known as Daphnellinae, attributed by Powell (1966) to Hedley, 1922, but by Kantor \& Sysoev (1986) to Casey, 1904. Taylor et al. (1993), following Ponder \& Warén (1988) attributed it to Deshayes, 1863. Bouchet \& Rocroi (2005) could not find this name in any of the publications of Deshayes, and argue that the name was first used by Casey (1904), as 'tribe' Daphnellini. For reasons of priority, the taxon should thus be named Raphitominae, as this name was introduced by Bellardi in 1875. Bouchet et al. (2011) seem to have overlooked the fact that Raphitomidae is based on a genus with a fossil type species (see discussion below), which conflicts with their ambitions to exclude all family names that cannot be applied to a molecular clade. This complicates their classification based on molecular data, as the relationship between the fossil type of Raphitoma and the Recent species of the 'genus' they included in the molecular analysis has not been resolved. Thus the member of 'Raphitoma' ('Raphitoma' rubroapicata (E.A. Smith, 1871)) included in the molecular analysis on which the family concept is based, is definitely not a Raphitoma as defined by the type species, or of the clade of Recent species from the North East Atlantic recognized as Raphitoma since 1984. More recently (WoRMS 2015) this species has been assigned to Etrema Hedley, 1918, which according to Bouchet et al. (2011) is a genus in Clathurellidae.

As is apparent from the abbreviated diagnosis above, the assignment of a genus to this family is anything but straightforward, and this impression is strengthened when looking at figures 7 (shells) and 8 (radula teeth) in Bouchet et al. (2011). However, as suggested by several authors (e.g. Powell 1966, Oliverio 1995, Kilburn 2009) the diagonally cancellated multispiral ('raphitomine') protoconch is (almost) diagnostic for the family. Inclusion of species with paucispiral protoconch is usually based on shell morphological similarity to species having multispiral protoconchs with the characteristic diagonally cancellated sculpture. The assignment should ideally be supported by other characters, e.g. type of radula or foregut anatomy or lack of operculum. The molecular phylogeny of Puillandre et al. (2011) largely support a classification based mainly on protoconch morphology, although a few divergent genera (i.e. Hemilienardia, Veprecula and 'Raphitoma' rubroapicata) included in the clade named Raphitomidae in their analysis, have multispiral protoconchs lacking the characteristic diagonally cancellated sculpture.

In Bouchet et al. (2011) some 60 genera are listed as valid, including both Philbertia (with Leufroyia as a synonym) and Cenodagreutes, in addition to Raphitoma. This list has been brought up to date in Bouchet (2015), in which 67 genera are accepted, and both Philbertia and Cenodagreutes are listed as synonyms of Raphitoma. In Bouchet et al. (2011) the Raphitomidae is cited as the largest and most variable taxon in the Conoidea, and is documented by 21 shell photos, eight radula photos and five protoconchs. None of these are of the name-bearing genus, Raphitoma. In Puillandre et al. (2008, 2011), two specimens purported to belong to Raphitoma are included, none of them belong to Raphitoma s.s.

\section{Genus Raphitoma Bellardi, 1847}

Type species - Raphitoma histrix Bellardi, 1847 (S.D. Monterosato 1872); Mediterranean Pliocene fossil. (See below and discussion in van Aartsen et al. 1984:88).

Cordieria Monterosato, 1884, non Roualt, 1848.

Cirillia Monterosato, 1884, non Rondani, 1856.

Cenodagreutes E.H. Smith, 1967.

Leufroyia Monterosato, 1884.

Lineotoma Nordsieck, 1977, nomen novum pro Cirillia Monterosato, 1884, non Rondani, 1856.

Philbertia Monterosato, 1884.

Members of Raphitoma are distinguished from other genera in the family by having a small to medium sized, elongated, turreted shell with uniformly convex whorls. Pronounced reticulate sculpture of strong axial ribs and strong spiral cords. A characteristic multispiral, cancellated, 'raphitomine' protoconch of 3 to 4 whorls (or similar species with paucispiral protoconchs).

Remarks. Northeast Atlantic species of this group have been shuttled between a host of different 'genera' during the last two centuries. Pleurotoma, Mangelia, Defrancia, Clathurella, Raphitoma have, at various times since the 1820ies been used for members of the group. Raphitoma was used in a wide sense by Bellardi (1847), but this usage was apparently not adopted by any of his contemporaries. Marshall (1912) settled for Clathurella, as Defrancia, preferred by Jeffreys (1867) was preoccupied. Philbertia Monterosato, 1884 (introduced by Monterosato in 1884 as a section within his new, but preoccupied, genus Cordieria) was adopted by Thiele (1929) as the most comprehensive genus-name for these species, with four subgenera and a number of sections. Raphitoma was regarded as a synonym of Mangelia Risso, 1826 by Thiele. (Curiously 
G.O. Sars 1878 had 'reintroduced' Raphitoma as a name for Teretia spp). Powell (1966) interpreted Philbertia more or less in the same way as Thiele. He used Raphitoma, for only two species, the Fossil Pleurotoma hystrix de Cristofori \& Jan, 1832 (cited as type species) and the Recent Clathurella pseudohystrix Sykes, 1906. Powell compared Raphitoma with the Indo-Pacific Veprecula Melvill, 1917 whose teleoconch sculpture is similar but with a different (non-raphitomine) protoconch sculpture. Powell did not directly compare his two Raphitoma species with the numerous North East Atlantic and Mediterranean species he included in Philbertia.

Based on the authority of Thiele and Powell, Philbertia has been universally accepted as the common name for all European species of Raphitoma sensu Bouchet \& Gofas 2015, until van Aartsen et al. (1984) decided that species with a planktotrophic protoconch needed a separate name. As Pleurotoma philberti (Michaud, 1829), the type species of Philbertia has a paucispiral protoconch, species with a multispiral protoconch should in their opinion be renamed. Van Aartsen et al. (1984) thus resurrected Raphitoma with Raphitoma histrix Bellardi, 1847, as type species.

Bouchet (1990) presented convincing arguments against placing species with planktotrophic protoconchs in different genera from similar-looking species with paucispiral protoconchs. This opinion has won almost universal approval (e.g. Oliverio 1996, Rolán et al. 1998, Pusateri et al. 2012). The reasoning used by van Aartsen et al. (1984) for introducing Raphitoma as a substitute for Philbertia for the species with a multispiral protoconch is thus unnecessary. However, as Raphitoma has priority it was reintroduced as the common name for this group, almost by default (it was not mentioned in Bouchet 1990).

The type species, Raphitoma histrix is a Mediterranean Pliocene fossil, originally known by a nomen nudum: Pleurotoma hystrix de Cristofori \& Jan, 1832 which was the name used for the type species by Monterosato (1872). Van Aartsen et al. (1984:89) point out that this nomen nudum was validated, in a slightly different spelling, as Raphitoma histrix, by Bellardi (1847:85). However, the correct identification of $R$. histrix has proved to be difficult, as the several specimens figured under this name apparently represent a number of different species. The specimen figured as Raphitoma histrix by Bellardi (1847) must be considered lost (van Aartsen et al. 1984). Van Aartsen et al. proposed to accept a specimen of Pleurotoma hystrix De Cristofori \& Jan, 1832, photographed by Pinna (1971) and later by Pinna \& Spezia (1978) as a 'syntype', as lectotype for the species. This solution to the problem is based on a number of unprovable assumptions, and will have to be discussed in a wider context by Mediterranean authors. Probably the matter is best served by designating a neotype.

\section{Species descriptions}

Below follows a description of each of the species found in inshore Norwegian waters. One species, $R$. cf. echinata is included in the key and illustrated, but not treated in detail, as it is not yet verified from the region defined as 'Norwegian' in this work (see Material and Methods above.).

Key to Norwegian members of Raphitoma.

1a. Protoconch with four whorls, microsculpture small granules or pustules or smooth 2

2a. Microsculpture of isolated small pustules 3

3a. Shell with white ground colour and purplish spiral cords. Narrow shells .................... R. aequalis $3 b$. Shell completely white (or colourless). Wide shells R. obesa n.sp.

2b. Microsculpture of small granules more or less merging together R. linearis

2c. Shell surface smooth and glossy, macrosculpture 'spiky' R. cf. echinata

1b. Protoconch with max. 3.5 whorls, microsculpture different 4

4a. Apex wide, axial ribs if present, wavy, fading away near aperture R. concinna 4b. Axial ribs strong and regular, detectable on siphonal canal 5

5a. Shell with elongated siphonal canal R. maculosa n.sp.

5 b. Solid shells with thickened outer lip with internal teeth R. purpurea

\section{Raphitoma maculosa n.sp.}

Figures $1 \mathrm{C}, 2 \mathrm{E}, 3 \mathrm{C}$ and $4-6$

http://zoobank.org/1A0C5382-5BC7-4EDE-880699054F8A5071

Murex reticulatus Renier, 1804 (Suppressed by ICZN)

Defrancia reticulata, Renier - Jeffreys 1867; Friele 1874

Clathurella reticulata, Ren. - G.O. Sars 1878

Clathurella reticulata, Brocc. - Marshall 1912

Raphitoma echinata - sensuSmith \& Heppell 1991; Heppell et al. 1997; Høisæter 2009, non Brocchi, 1814.

Raphitoma asperrima (Brown, 1827) - Fretter \& Graham 1985 [in part]; Graham 1988 [in part];

Philbertia asperrima (Brown, 1827) - Hubendick \& Warén 1976 [in part]; Høisæter 1986

Type material. Holotype ZMBN 107134.

Type locality. Liholmsrennen, Raunefjorden, Hordaland county, $60^{\circ} 18^{\prime} \mathrm{N}, 05^{\circ} 09^{\prime} \mathrm{E}$; 70-90 m. 

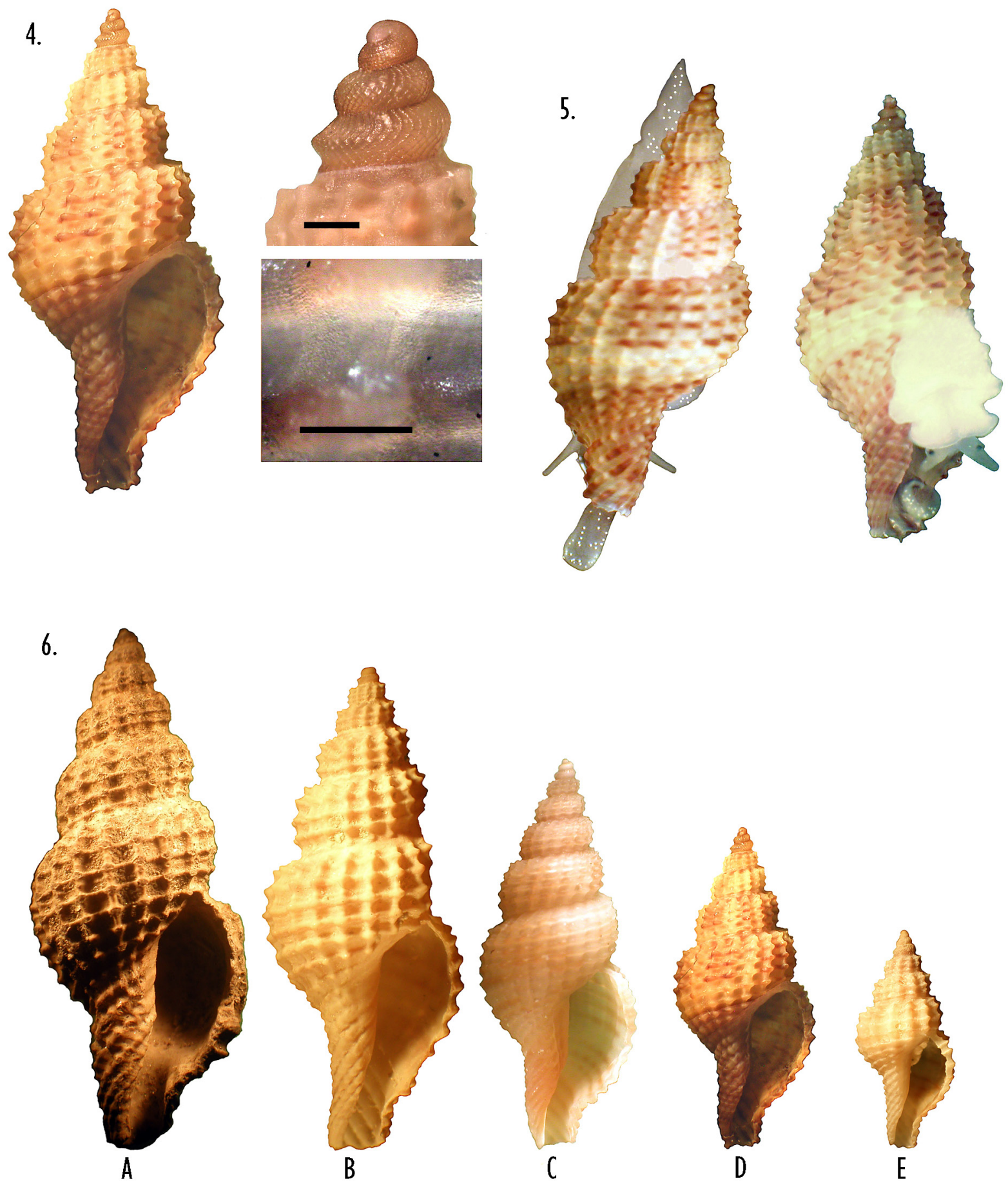

Figure 4. Raphitoma maculosa n.sp. Holotype, $7.2 \mathrm{~mm}$ long. From Liholmsrennen, Raunefjorden, $60^{\circ} 18^{\prime} \mathrm{N}, 05^{\circ} 09^{\prime} \mathrm{E}, 70-90 \mathrm{~m}$. (ZMBN 107134). Microsculpture from a specimen from Bodø (Figure 6C). Scale bar $=200 \mu \mathrm{m}$.

Figure 5. Raphitoma maculosa n.sp. Holotype $7.2 \mathrm{~mm}$, photographed alive in a petri-dish.

Figure 6. Five shells of Raphitoma maculosa n.sp. Shells to scale, the largest $11.8 \mathrm{~mm}$. A. ZMBN 15527 (Jondal, 50-120 m); B. East of Andøya $69^{\circ} 17^{\prime} \mathrm{N}, 60-80 \mathrm{~m}$; C. North of Store Hjartøy, Bodø $67^{\circ} 18.5^{\prime} \mathrm{N}$, $70 \mathrm{~m}$; D. Liholmsrennen, Raunefjorden, $60^{\circ} 18^{\prime} \mathrm{N}, 05^{\circ} 09^{\prime} \mathrm{E}, 70-90$ m; E. Kinnarosen $60^{\circ} 14^{\prime} \mathrm{N}, 120-100 \mathrm{~m}$. 
Etymology. From Latin macula, spot, stain, mark. Referring to the white spots sprinkled all over the head-foot complex.

Material examined. One specimen (holotype) (70-90 m) and one shell (120-100 m) from Raunefjorden, western Norway, and one specimen $(70 \mathrm{~m})$ and one shell $(80-60 \mathrm{~m})$ from northern Norway. A shell from Bergen (ZMBN 16639) and one from Jondal, Hardanger, 50-120 m (ZMBN 15527).

Description. (Based mainly on the holotype, the specimen studied alive, from Liholmsrennen, Raunefjorden, Figures 4 and 5). Max size $10.8 \mathrm{~mm}$ (Figure 6A). Shell fairly thick and opaque; height 2.27 to 2.47 times the diameter; apical angle $48^{\circ}$. Body whorl $65-69 \%$ of total shell height. Shell colour, judging from the specimen in Figure 5 (photographed alive), with ground colour light yellowish white, with most spiral cords reddish brown on the nodules, much lighter brown on the cords between ribs. Spiral cords no. 5 and 6 from the top on the body whorl much lighter coloured than the rest. The shell has a more 'spotted' appearance than the other species in the genus. Protoconch (Figures $3 \mathrm{C}$ and 4) with 3 to $3 \frac{1}{2}$ whorls, with a coarse decussate grid and ending in a weak spiral keel. Protoconch W/L: 0.96. Protoconch colour milk chocolate brown. The $7.2 \mathrm{~mm}$ long specimen has four and a half teleoconch, convex whorls, with a deep and distinct suture. Sculpture consisting of numerous, slightly prosocline axial ribs crossed by spiral cords. Five or six narrow cords on penultimate whorl. The narrow axial ribs create, together with the strong spiral cords, a pattern of deep trapezoid pits wider than high (Figure 1C). Aperture narrow with a long and narrow siphonal canal, with eight spiral cords below 'bend' in siphonal canal (counted on dorsal side of the shell). Microsculpture not very distinct but apparently somewhat diffuse, small irregular oblong granules (Figure 4).

Foot with numerous bright white spots on a more diffuse gray-white background (Figure 5). The siphon extends a long distance in front of the siphonal canal, and appears somewhat bulb-shaped in front with 30 to 40 opaque white spots on the slightly grayish background.

Variability. The variability of the sculpture is well illustrated in Figure 6B and $\mathrm{C}$, depicting two shells from northern Norway. The empty shell from Andfjorden (Figure $6 \mathrm{~B}$ ) has a more coarse sculpture with fewer axial ribs and fewer and stronger spiral cords than the specimen from Hjartøy just west of Bodø (Figure 6C). The available material (five shells, of which three are rather worn) does not permit a more detailed description of the shell variability.

Distribution. In Norway reported (as $R$. reticulata) as rare from narrow inlets in the archipelago north of Bergen (around $60^{\circ} 35^{\prime} \mathrm{N}$ ) (Friele 1874). Not found by Norman (1879). In my large material of shells of Raphitoma s.l. from most of the Norwegian coast, only two specimens and two shells may reasonably be referred to this species. It is thus presumably distributed from Hardangerfjorden south of Bergen to Andfjorden $\left(69^{\circ} 17^{\prime} \mathrm{N}\right.$, 60-80 m; only empty shell found). The specimen from Hjartøy in Nordland $\left(67^{\circ} 18^{\prime} \mathrm{N}, 60 \mathrm{~m}\right)$ indicates that it is still (1976) present in northern Norway. The distribution outside Norway is unknown because of possible confusion with $R$. cf. echinata (see below).

Remarks. This species was called Raphitoma echinata (Brocchi, 1814) in Høisæter (2009), based on the assumption that it was conspecific with the species given this name in several fairly recent check-lists from the British Isles (e.g. Smith \& Heppell 1991, Heppell et al. 1997). The species is called Raphitoma asperrima (Brown, 1827) in other North European identification guides (Hubendick \& Warén 1976, Fretter \& Graham 1985, Graham 1988). The name 'asperrima' was first used for a 'variety' of $R$. purpurea (Montagu, 1803) by Forbes \& Hanley (1853), but according to Jeffreys (1867:318), the type of Brown's Fusus asperrimus was a shell of Trophonopsis muricatus (Montagu, 1803). This synonymy I find reasonable, based on the drawing in Brown (1827). This synonymy is also accepted in WoRMS (Gofas 2015a).

The name R. echinata (Brocchi, 1814) for a British species was introduced indirectly by Jeffreys (1867), as he picked the oldest (Murex reticulatus) of several names for a complex of Mediterranean shells that he regarded as synonyms ("It is...M. echinatus of Brocchi, Pleurotoma Cordieri of Payraudeau, P. rude of Scacchi =[Raphitoma pupoides (Monterosato, 1884) $]$ "). Murex reticulatus Renieri, 1804, was suppressed by ICZN (Opinion 316 Dec. 17, 1954) and Murex echinatus Brocchi, 1814, based on a fossil, was (on the authority of Brocchi 1814 and Monterosato 1884) introduced as a subjective synonym of the unavailable M. reticulatus. Whether the Mediterranean $R$. echinata is really conspecific with the British species discussed by Jeffreys, is impossible to verify until the Mediterranean species complex to which $R$. echinata belongs is properly revised.

Jeffreys had, however, described the British species already in 1847 under the name Pleurotoma scabrum ("I described the present species (D. reticulata Renier) as P. scabrum under the impression that it was distinct from the Mediterranean shell and not merely a variety"). A photograph of a syntype of this species is presented in Warén (1980, Pl. 6, Fig. 12). Unfortunately this photograph is too small to reveal any details of the sculpture of the shell. One important detail visible is the short siphonal canal, shorter than in my specimens of R. maculosa. Combined with the description in Jeffreys (1847) and the more detailed one (for D. reticulata) in Jeffreys (1867) it is anyway possible to compare the British species with my Norwegian specimens. In 1847, Jeffreys compared his $P$. scabrum with $R$. linearis: "It differs from $\mathrm{Pl}$. lineare in the volutions being more tapering, and generally in its more slender form, and in the ribs and transverse striæ being sharper and more elevated, giving the shell a scabrous appearance." Although it cannot be completely excluded that Jeffreys' $P$. scabrum is conspecific with $R$. maculosa $\mathrm{n}$.sp., the fact that scabrum has not been used since Jeffreys listed it as a synonym of $R$. reticulata in 1867, argues for rejecting the name as a nomen oblitum according to the rules in ICZN. 
A complicating factor is the presence in British waters of another species belonging to the same species complex, but never having been formally accepted as a separate species. This species is represented in my material by a single $11.1 \mathrm{~mm}$ long shell from $138 \mathrm{~m}$, near Gullfaks oil field $61^{\circ} 05^{\prime} \mathrm{N}$, on the western slope of the Norwegian Trench (Figure 7). Its main difference from $R$. maculosa, in addition to the very spiky 'nodules' is the smooth, almost satiny surface between the spiral cords, only interrupted by lines of growth. A similar looking shell from Shetland is illustrated in Fretter \& Graham (1985) under the name $R$. asperrima (Brown). I suspect, based on the drawing in combination with their detailed description that Fretter \& Graham actually used both specimens of $R$. maculosa n.sp. and the species illustrated in Figure 7 as basis for their R. asperrima. As Fusus asperrima Brown is accepted as a synonym of Trophonopsis muricatus (see above), the shell shown in Figure 7, needs another name. It might be a British form of R. echinata, but as this subgroup of Mediterranean Raphitoma [R. echinata, R. cordieri and R. horrida (Monterosato, 1884)] are yet to be properly revised, and their shell surface judging from available illustrations on the internet, is more porcellaneous than satiny, it might be better to choose a name based on British material. R. formosa (Jeffreys, 1867) is a candidate, but I feel it prudent to rather emphasize its similarity to one of several recent species of the Mediterranean R. echinata group (e.g. Gofas et al. 2011) as $R$. cf. echinata.

\section{Raphitoma aequalis (Jeffreys, 1867)}

Figures 2B, C, 3B and $8-11$

Defrancia linearis var. aequalis Jeffreys, 1867:369

Cordieria (Cirillia) aequalis, Jeffr. - Monterosato 1884

Clathurella cequalis, de MonTEROSATO - Locard 1892

Mangelia linearis var. intermedia Forbes \& Hanley, 1853:472

Clathurella linearis var. intermedia F. and H. - Marshall 1912

Pleurotoma (Pleurotomoides) cequalis (Jeffreys)

Monterosato - Dautzenberg \& Fischer 1925

Cenodagreutes aethus_E.H. Smith, 1967a:1

Philbertia linearis aequalis (Jeffreys) - Rodriguez Babio \& Thiriot-Quiévreux 1974

Raphitoma aequalis (Jeffreys, 1867) - Sabelli et al. 1990; Cachia et al. 2001; Høisæter 2009

Defrancia linearis (Montagu, 1803) [in part] - Friele 1874

Clathurella linearis - G.O. Sars 1878

Philbertia linearis (Montagu, 1803) [in part] - Hubendick \& Warén 1976; Høisæter 1986

Raphitoma linearis (Montagu, 1803) [in part] - van Aartsen et al. 1984 (?); Fretter \& Graham 1985; Graham 1988; Smith \& Heppell 1991; Olsen 1994 (?); Heppell et al. 1997

Type material. Types could not be found (Warén 1980).
Holotype and one paratype of Cenodagreutes aethus E.H. Smith, 1967, in California Academy of Sciences, Department of Invertebrate Zoology, Type number 320 (holotype) and 321, see Figure 10 below.

Type locality. Great Britain. Type locality for Cenodagreutes aethus E.H. Smith, 1967, off Farland Point, Isle

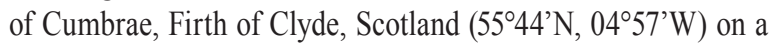
bottom of stones and mud in $20 \mathrm{~m}$.

Material examined. Around 245 specimens from 85 stations between $58^{\circ}$ and $69^{\circ} \mathrm{N}$ on the coast of Norway.

Description. (Based mainly on specimens illustrated in Figures 8 and 11A). The size of the specimen in Figure 8, 10.1 $\mathrm{mm}$, is the maximum recorded for the species. Shell moderately narrow (height rarely more than 2.25 times the diameter). Body whorl 53 to $70 \%$ of total shell height. Shell subfusiform with convex whorls and with deeply incised sutures. Sculpture of moderately pronounced axial ribs (costae) crossed by narrow spiral cords, six cords on penultimate whorl. The space between spiral cords two to three times wider than the spiral cords. Where the cords cross the ribs, rather low, smooth and glossy tubercles are produced. Axial ribs disappear gradually towards the base. Yellowish white to golden yellow ground colour with reddish brown spiral cords. On penultimate whorl, the sixth (or seventh) spiral cord from top often white or much lighter than remaining cords. Every second or third rib pure white in some specimens. In specimens from deeper water, ground colour usually almost white and spiral cords with much less pigment than in those from shallower water (Figures $11 \mathrm{~F}$ and H). Aperture an elongated oval drawn out into a siphonal canal of varying length, longer in juveniles than in adults, but never as long as in equally long $R$. maculosa $\mathrm{n}$.sp. Shallow anal sinus in outer lip near suture. Spiral cords on the siphonal canal smooth, wider and closer together than on the whorls above the aperture. Teleoconch microsculpture of fine, well separated microscopic pustules (Figures 2B, C and 8), best visible between spiral cords in upper parts or in juvenile shells. Protoconch of 3.5 to 4 (varies) light brown, convex whorls (Figures 3B and 8). Protoconch W/L: 0.97 . Apical angle $50^{\circ}$ to $54^{\circ}$. Apical whorl from 180 to $220 \mu \mathrm{m}$ in diameter. Protoconch ending in a weak spiral keel.

A specimen observed alive in a petri-dish (Figure 9) turned out to be rather sedate. It crawled slowly along in its preferred direction, with the siphon extending only a fraction of a $\mathrm{mm}$ in front of the siphonal canal. The foot is wide, tapering to a narrow point posteriorly and has distinctly recurved anterolateral corners. The foot and siphon is uniformly white.

Variability. This is a variable species, both as regards colour and shape (Figure 11). The Height to width ratio varies a lot as does the length and width of the siphonal canal. The colour may be light yellowish white with scattered light brown spiral cords, or darker yellow with reddish brown cords. However the colour is fading fast in preserved specimens and thus the colours in the descriptions may not be completely reliable. The colour pattern appears to vary geographically as 

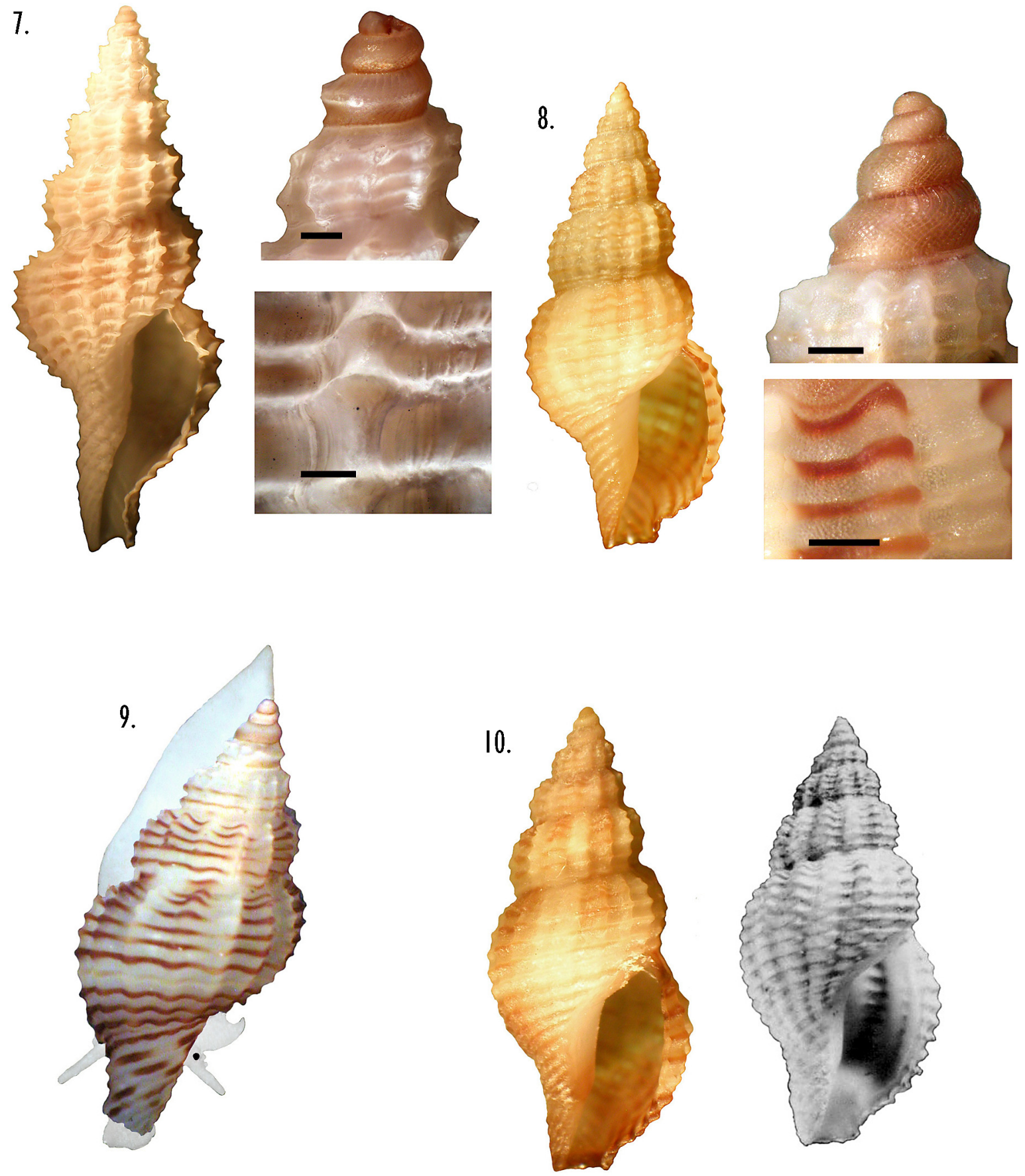

Figure 7. A shell of Raphitoma cf. echinata $11.1 \mathrm{~mm}$, from $138 \mathrm{~m}$, near Gullfaks oil field $61^{\circ} 05^{\prime} \mathrm{N}$.

Figure 8. Raphitoma aequalis. $10.1 \mathrm{~mm}$. From Kvæfjord in Troms county, $68^{\circ} 50^{\prime} \mathrm{N}, 30 \mathrm{~m}$. The protoconch from a juvenile from $67^{\circ} 15^{\prime} \mathrm{N}$ and microsculpture from a juvenile from Bukkasundet, $60^{\circ} 15^{\prime} \mathrm{N}$ (Figure 11G). Scale bars $=200 \mu \mathrm{m}$.

Figure 9. Raphitoma aequalis. A specimen photographed crawling in a petri-dish. Specimen from Hillersholmen (Figure 11D), $5.2 \mathrm{~mm}$. Figure 10. Cenodagreutes aethus. Holotype, (from E.H. Smith 1967a) right, together with a specimen of R. aequalis from Grovfjord (Figure 11A). 
well, as there is a much higher proportion of specimens with very light coloured spiral cords in the material from Skagerrak than in the material from further north on the coast. Fretter \& Graham (1985) mention a row of nine small teeth on inside of outer lip (as $R$. linearis see below), but this is very rarely the case even for large specimens in my material. The most reliable characters are the microsculpture consisting of well separated small pustules and the light brown wide angled protoconch with delicate diamond-shaped decussate sculpture.

Distribution. By Jeffreys (1867) stated to be more common in the northern parts of British waters than in the south, but with a distribution overlapping the one of $R$. linearis. Recorded from Malta (Cachia et al. 2001) and Italy (Spada 2008) in the Mediterranean to Finnmark (as R. linearis in G.O. Sars 1878). The latter record is based on a single empty shell from Hammerfest $\left(71^{\circ} \mathrm{N}\right)$. In addition G.O. Sars reports a single specimen (live caught) from Lofoten. Judging from his drawing and description (in latin), the $9.5 \mathrm{~mm}$ long specimen is certainly $R$. aequalis and not $R$. linearis (see also citation of Marshall 1912, below). In my material common along the whole coast at least as far north as Kvæfjord, $68^{\circ} 50^{\prime} \mathrm{N}$, in Troms county, but especially frequent (105 of the c. 245 live caught specimens) from the area just north of Bodø, at $67^{\circ} 15^{\prime} \mathrm{N}$ (mainly due to very diligent collecting efforts of Per Wikander, thus not necessarily more common there than elsewhere in northern Norway).

Remarks. Described by Jeffreys (1867:369) as a variety
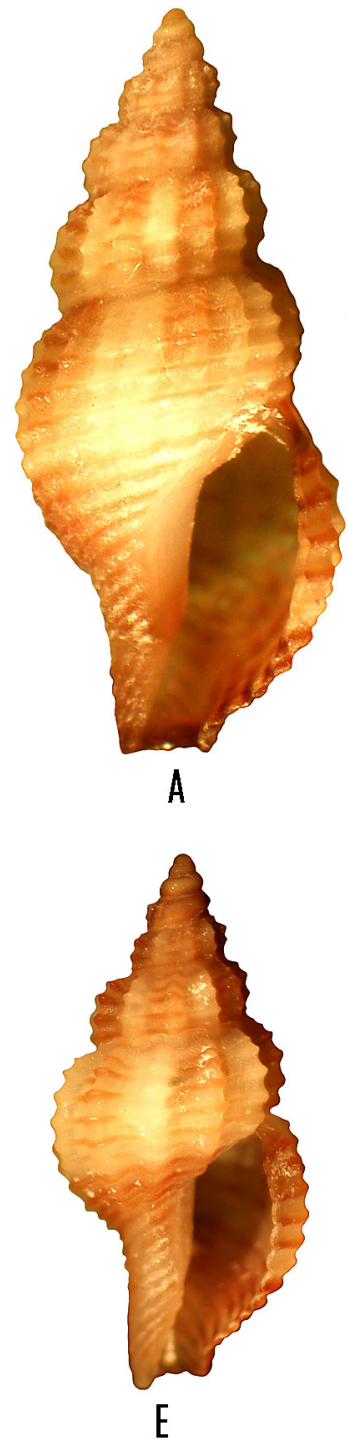
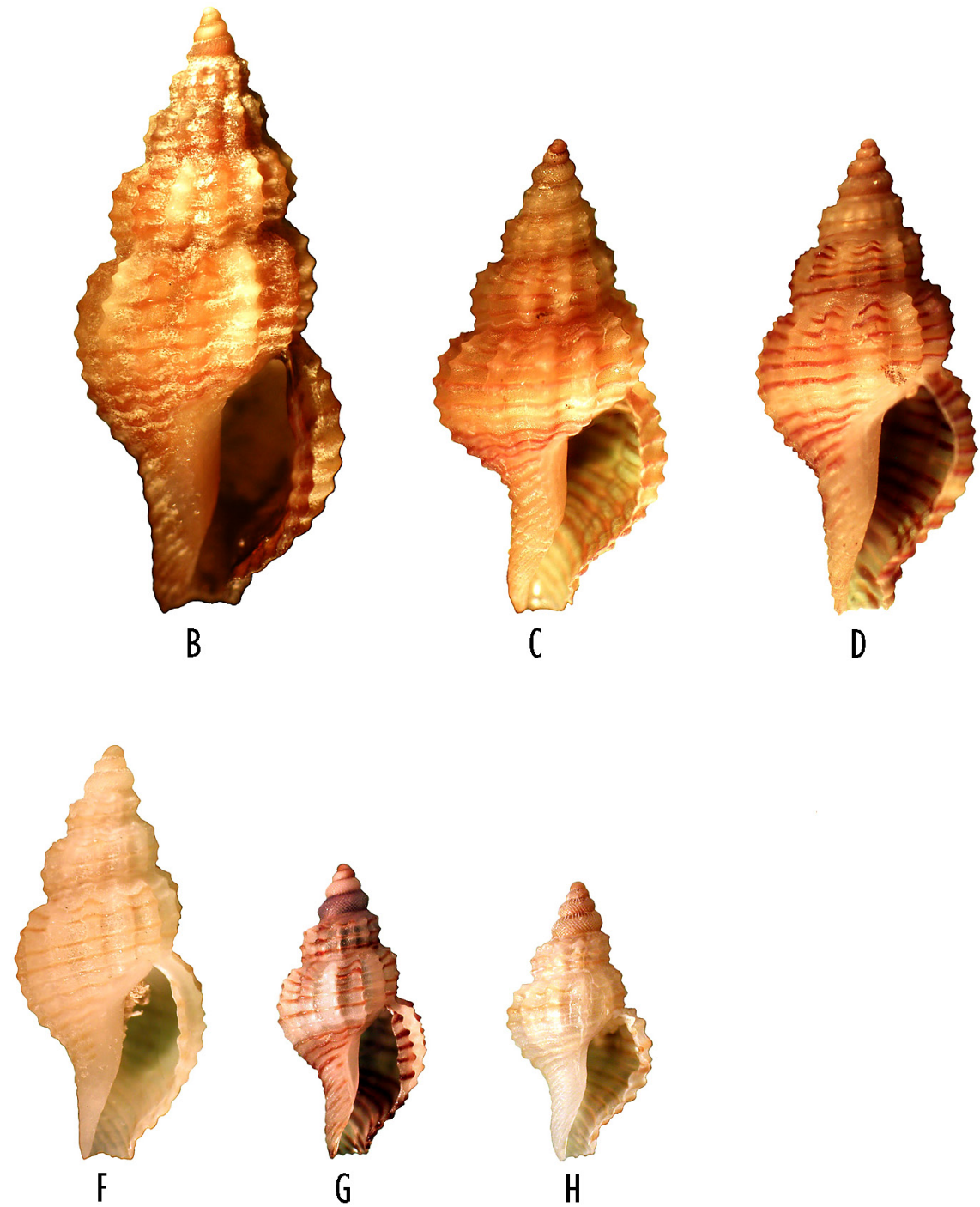

Figure II. Raphitoma aequalis, eight specimens showing variability of the species in Norway. Specimens to scale, the largest $6.5 \mathrm{~mm}$. A. Grovfjord, $68^{\circ} 51^{\prime} \mathrm{N}, 16^{\circ} 30^{\prime} \mathrm{E}, 10 \mathrm{~m}$; B. Bukkasundet, $60^{\circ} 15^{\prime} \mathrm{N}, 05^{\circ} 17^{\prime} \mathrm{E}, 8-15 \mathrm{~m}$; C. Liholmsrennen, $60^{\circ} 18^{\prime} \mathrm{N}, 05^{\circ} 09^{\prime} \mathrm{E}, 70-90 \mathrm{~m}$; D. Hillersholmen, $60^{\circ} 18^{\prime} \mathrm{N}, 05^{\circ} 15^{\prime} \mathrm{E}, 8 \mathrm{~m}$ (2007); E. Hillersholmen, $60^{\circ} 18^{\prime} \mathrm{N}, 05^{\circ} 15^{\prime} \mathrm{E}, 8 \mathrm{~m}$ (1967); F. Near Grimstad, $58^{\circ} 22^{\prime} \mathrm{N}, 08^{\circ} 48^{\prime} \mathrm{E}, 57$

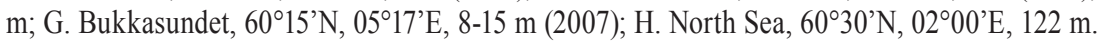


of $R$. linearis: "Shell broader than the typical form, with the whorls more rounded; ribs more numerous, and not so prominent or rugged; spiral striae closer or finer; apex yellowish white; coloured lines regularly distributed, and of a paler hue; in some specimens these markings are very faint or altogether wanting. L. 0.5. B. 0.225." In a general way these characters match my material, but the 'apex' is rarely yellowish white. Monterosato (1884) was the first to elevate the 'variety' to full specific status, followed by among others Locard (1892) and Dautzenberg \& Fischer (1925), the latter based on material from the vicinity of Roscoff, Bretagne. Rodriguez Babio \& Thiriot-Quiévreux (1974) reported the two forms from Roscoff, but retained aequalis as a variety of linearis primarily based on the similarity of the protoconchs. They noted that in the vicinity of Roscoff, linearis was four times as common as aequalis.

Forbes \& Hanley (1853:471-472) described three 'principal varieties' of Mangelia linearis, the purple-tipped (var. scabra), the blunt-ribbed (var. intermedia) and the colourless form (var. pallida). Even from this brief sentence it is tempting to equate the three varieties with respectively $R$. linearis, $R$. aequalis and $R$. obesa n.sp. Jeffreys (1867:369) introduced another 'variety', Var. aequalis, which he explicitly states is a new name for the two 'varieties' Mangelia linearis vars intermedia and pallida of Forbes \& Hanley. Jeffreys thus merges the two varieties of Forbes \& Hanley, as he regards the difference between the 'blunt-ribbed' form and the 'colourless' form as too small or vague to justify giving a name to the colourless (or pure white) form of the species: “...in some specimens (of Var. aequalis) these markings are very faint or altogether wanting." Jeffreys (1867:369).

Marshall (1912:299) disagreed with Jeffreys' merging and renaming of the 'varieties', mentioning that $R$. linearis as well as the two 'varieties' intermedia and pallida described and figured by Forbes \& Hanley (1853) were three validly described 'varieties'. If this is accepted, $R$. aequalis is a junior synonym of $R$. intermedia, while $R$. obesa $\mathrm{n}$.sp. is a junior synonym of $R$. pallida. Since $R$. aequalis has been generally accepted as a full species since it was adopted by Monterosato (1884), while $R$. intermedia and $R$. pallida have never been used as valid names after Marshall (1912), they are better regarded as nomina oblita according to Article 23.9.2 of ICZN.

In North European literature, $R$. aequalis, has long been treated as a synonym of $R$. linearis. As already noted by Marshall (1912:299), the records of $R$. linearis in G.O. Sars (1878) from northern Norway are of this species (... except Sars' fig. 2 (t. 23), which well represents the var. intermedia). Also Fretter \& Graham (1985) described and illustrated (their figures 368 and 369) $R$. aequalis as $R$. linearis. Their SEM photograph of the transition zone between protoconch and teleoconch particularly clearly shows the microsculpture (fine pustules) found in $R$. aequalis but not in R. linearis. E.H. Smith (1967a) may have been the first (after Jeffreys 1867) to clearly distinguish between these two species in British waters (see Discussion below), although he did not realise that he dealt with already described taxa.

\section{Raphitoma obesa n.sp.}

Figures 2D, 12 and 13

http://zoobank.org/98E86ED3-235C-41E8-BB26458ABE6A5F1C

Clathurella linearis var. pallida F. and H. - Marshall 1912:298 (?)

Raphitoma n.sp. - Høisæter 2009

Type material. Holotype ZMBN 107135.

Type locality. Svinestangen, Korsfjorden, Hordaland, Norway, $60^{\circ} 12^{\prime} \mathrm{N}, 5^{\circ} 10^{\prime} \mathrm{E}, \mathrm{c} .100 \mathrm{~m}$.

Etymology. From Latin obesus, fat. Referring to the shape of the shell.

Material examined. Only the holotype; a specimen from Liholmsrennen, $60^{\circ} 17^{\prime} \mathrm{N}, 5^{\circ} 09^{\prime} \mathrm{E}$, 80-95 m (shell destroyed when sample taken for DNA-analysis); a specimen from west of Frøo, Øygarden, $60^{\circ} 35^{\prime} \mathrm{N}, 70-75 \mathrm{~m}$; one from Mandnesholmen, Nesna, 66 $64^{\circ} \mathrm{N}, 65-63 \mathrm{~m}$; and one from Lille Hjartøy, Bodø, $67^{\circ} 17^{\prime} \mathrm{N}, 70-60 \mathrm{~m}$.

Description. Holotype (Figure 12) 7.0 x $3.6 \mathrm{~mm}$, with five teleoconch whorls. Shell subfusiform with convex whorls and deeply incised sutures. Shell thin, glassy, wide (height 2.1 times the diameter). Spire occupying $34 \%$ of total shell height. Diameter of adapical teleoconch whorl $745-970 \mu \mathrm{m}$. Sculpture of moderately pronounced axial ribs crossed by fairly narrow spiral cords, six cords on penultimate whorl. The axial ribs disappear gradually towards the base. Shell yellowish white with spiral cords usually unpigmented, but sometimes with weak golden brown pigment. The ribs are narrow and separated by a wide 'valley', these being from 2 to 2.5 times as wide as the ribs. The rectangles defined by the cords and ribs are twice as wide as high. The surface between the spiral cords densely covered with fine, well separated, microscopic pustules (Figures 2D and 12), best observed between spiral cords in upper parts or in juvenile shells. The nodules produced by the crossing of cords and ribs distinct but not very acute, when seen in profile producing a 'wavy' aspect. Aperture occupying $47 \%$ of total shell height, aperture width about $41 \%$ of its height. Outer lip slightly undulating with an anal sinus near the suture almost rectangular with a width $90 \%$ of its depth. Usually dense, but not very sharp growth lines between axial ribs (Figure 12). Siphonal canal moderately long, about $27 \%$ of total shell height. No axial ribs on siphonal canal, but spirals wider and denser together than on the whorls proper. Protoconch with 3.5 to-4 pale, yellowish white whorls (same colour as teleoconch). Protoconch W/L: 0.96 . Apical angle $c$. 50.5 . Apical whorl 160 to $180 \mu \mathrm{m}$ in diameter. Apical whorl and half of the following with about nine to ten microscopic spiral striae; the next with decussate sculpture, the next with numerous slightly curved axial riblets on top third and delicate decussate grid on bottom two thirds of whorl. Protoconch ending in a weak spiral keel. 

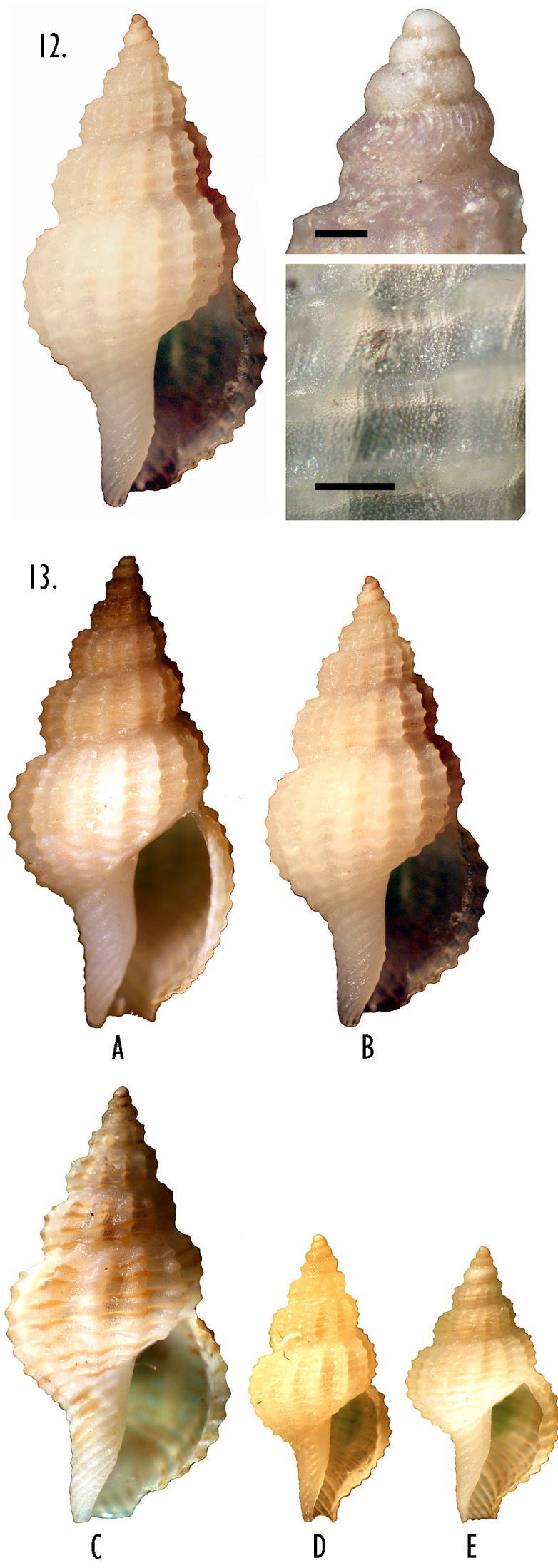

Variability. The limited material does not permit a thorough description of morphological variation, but as is evident from Figure 13, a specimen from northern Norway (Figure 13E) is much wider than the three from western Norway (Figures 13A, $\mathrm{B}, \mathrm{D})$. The lack of pigment on spiral cords is not absolute, as seen in Figure 13C.

Distribution. So far only found in fjords on the western coast of Norway, 80-100 m depth, mixed bottom material, and at two localities in Nordland county $\left(66^{\circ}-67^{\circ} \mathrm{N}, 60-70 \mathrm{~m}\right.$ depth). Recently reported from the Kola inlet on the Murman coast of Russia (Nekhaev 2014, as Raphitoma leufroyi), based on an empty shell, almost indistinguishable from Figure 13C above.

Remarks. This species was briefly described as Raphitoma n. sp. in Høisæter (2009). It may have been described (as the variety pallida of $R$. linearis) already by Forbes \& Hanley (1853:471-472). As several forms of $R$. aequalis are practically colourless, the description of Forbes \& Hanley (1853:472) is too vague to confirm that their 'variety' is the same as $R$. obesa n.sp ("The variety pallida is essentially northern: it is more or less devoid of colouring, has still finer closer and less elevated sculpture, and is even more produced in shape than the richly tinted and prickly southern variety"). Jeffreys (1867:369) merged this 'variety' with 'var.' intermedia thus rejecting the existence of a separate 'colourless' variety. Marshall fully agrees with Forbes \& Hanley in this matter, and objects to Jeffreys' merging of the two 'varieties' to the 'variety' aequalis. Marshall's opinion concerning the status of Var. pallida F. and $\mathrm{H}$. is somewhat equivocal, however, as he equals this variety with var. aequalis Jeff., while no such equality is claimed for var. intermedia. Anyway, as stated for $R$. aequalis above, the name pallida is better regarded as a nomen oblitum according to Article 23.9.2 of ICZN.

The most conspicuous difference from $R$. aequalis is the almost complete lack of colour pattern, and the comparatively wider body whorl. The shell is thinner and almost translucent. The protoconch is invariably of the same hue as the teleoconch (whitish or slightly yellowish), while that of $R$. aequalis is of a golden yellow-brown hue, sometimes with a whitish apical whorl. Whether it is a good species or not is impossible to conclude based on the available material. Three morphological character states support a specific status, the shape of the shell, the scarcity of shell pigment, and the shape of the columella in fully grown specimens. Also the microsculpture with distinct

Figure 12. Raphitoma obesa n.sp. Holotype, $7.0 \mathrm{~mm}$ long. From Svinestangen, $60^{\circ} 12^{\prime} \mathrm{N}, 5^{\circ} 10^{\prime} \mathrm{E}$, c. $100 \mathrm{~m}$ (ZMBN 107135). Protoconch and detail of sculpture from specimen from Liholmsrennen, 80-95 m (Figure 13A). Scale bars $=200 \mu \mathrm{m}$.

Figure 13. Five specimens of Raphitoma obesa n.sp. showing variability. Specimens to scale, the largest $7.35 \mathrm{~mm}$ long. A. Liholmsrennen, 80-95 m; B. Svinestangen, Korsfjorden, c. 100

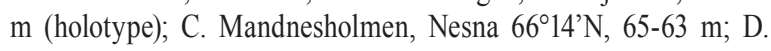
West of Frøo, Øygarden, 70-75 m; E. Lille Hjartøy, Bodø 67¹7’N, 70-60 m. 
and well separated pustules on the partly transparent shell support a specific status. In addition the lack of protoconch colour argues for a separate taxon. The considerable variability in the morphology of $R$. aequalis certainly does not make it easier to decide. All things considered using the name, Raphitoma obesa n.sp. for these five specimens is the best basis for future studies, preferably by molecular methods.

\section{Raphitoma linearis (Montagu, 1803)}

Figures 1A, 2A, 3A and $14-17$

Murex linearis Montagu, 1803:261, Tab. 9, f. 4

Defrancia linearis (Montagu, 1803) - Jeffreys 1867; Friele 1874; Norman 1879 [in part]

Clathurella linearis, Mont. [in part] - G.O. Sars 1878

Cirillia linearis, Mtg. - Monterosato 1884

Philbertia linearis (Montagu, 1803) - Rodriguez Babio \& Thiriot-Quiévreux 1974; Hubendick \& Warén 1976 [in part]; Høisæter 1986 [in part]

Raphitoma linearis (Montagu, 1803) - Rolán 1983 [in part?]; Fretter \& Graham 1985 [in part]; Graham 1988 [in part]; Sabelli et al. 1990; Rolán et al. 1998; Cachia et al. 2001; Öztürk et al. 2004; Høisæter 2009

Raphitoma (R.) linearis (Montagu, 1803) - van Aartsen et al. 1984 [in part?]; Smith \& Heppell 1991 [in part]; Heppell et al. 1997 [in part]

Cenodagreutes coccyginus E.H. Smith, 1967a:3

Type material. Lectotype designated by Rolán et al. (1998),
BMNH 1995090 (one of several syntypes). Holotype and one paratype of Cenodagreutes coccyginus E.H. Smith, 1967, in California Academy of Sciences, Department of Invertebrate Zoology, Type number 322 (holotype) and 323. Photographs of both types shown in Figure 17 below.

Type locality. Falmouth Harbour, Cornwall, England. Type locality for Cenodagreutes coccyginus E.H. Smith, 1967, off Tan Buoy between Great Cumbrae and Little Cumbrae Islands,

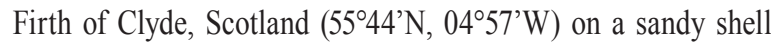
bottom in $17 \mathrm{~m}$.

Material examined. Ninety-seven specimens from 36 stations from $c .58^{\circ}$ to $61^{\circ} \mathrm{N}$ on the coast of Norway.

Description. Based mainly on a specimen from Bukkasundet (1966), $7.4 \times 3.5 \mathrm{~mm}$, (Figure 16A), and another from Bukkasundet (2007), 5.9 × $2.8 \mathrm{~mm}$, (Figure 14). Shell fairly thick and opaque; moderately narrow. Shells longer than $4.9 \mathrm{~mm}$ with height 2.10 to 2.32 times the diameter, and body whorl $64-70 \%$ of total shell height. Shell colour varies, but always with a comparatively light ground colour and dark brown nodules on the axial ribs, alternating with scattered ribs with white nodules. Spiral cords nos 5 and 7 from above on penultimate whorl, with uninterrupted dark brown colour, while the spiral cord between these two is pure white (Figures 14 and 15). Ground colour darker on adapical teleoconch whorl and below periphery on body whorl. Five teleoconch whorls (on 7.4 $\mathrm{mm}$ long shell) convex (but varying a lot, see below) with a deep and distinct suture. Adapical teleoconch whorl 625-925 $\mu \mathrm{m}$ in diameter. Sculpture of axial ribs crossed by spiral cords, five or six narrow cords, the uppermost distinctly less prominent than the rest, on the penultimate whorl. The interspaces are around
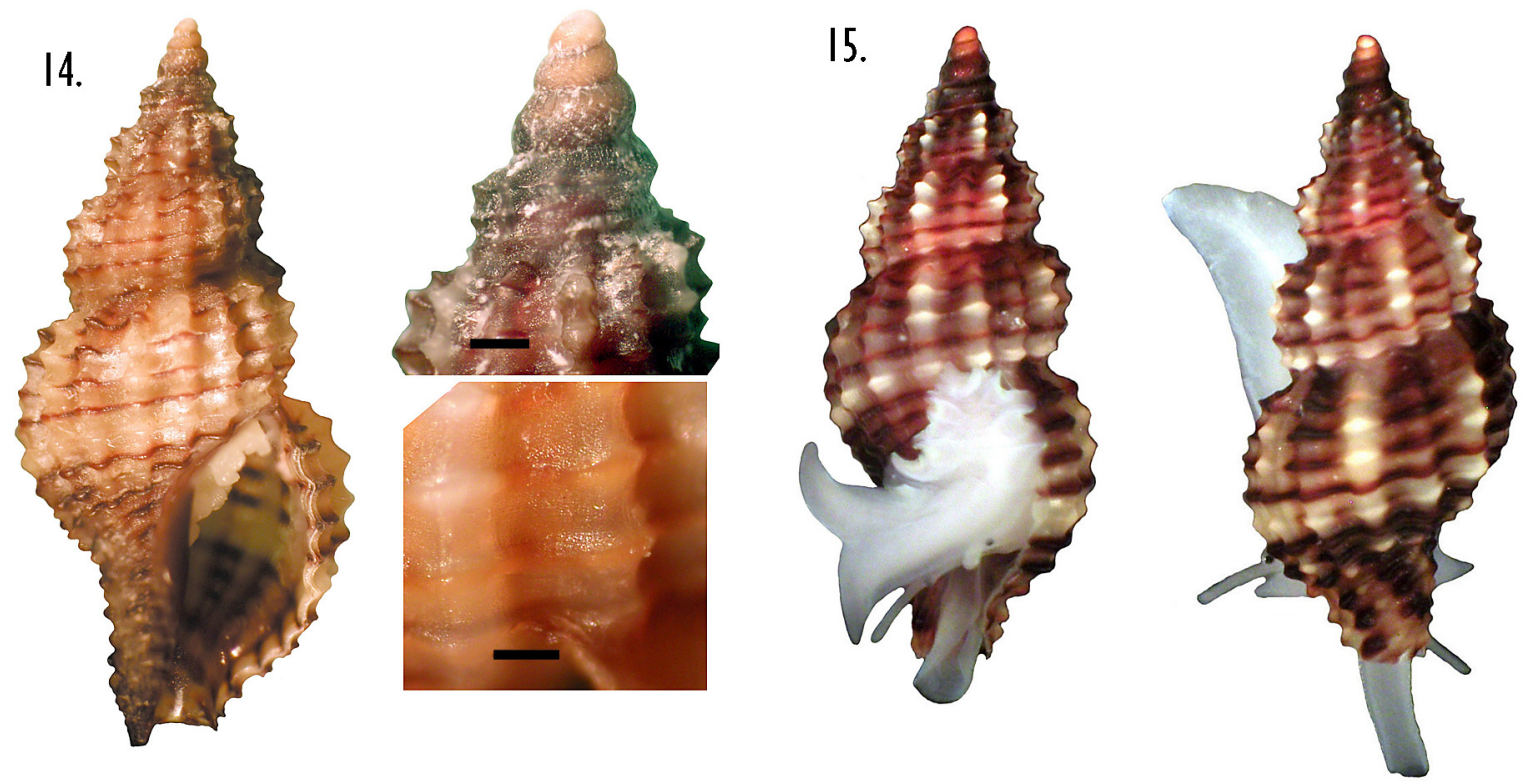

Figure 14. Raphitoma linearis, $5.9 \mathrm{~mm}$. From Bukkasundet, Raunefjorden, 60¹4’N, $10 \mathrm{~m}$. Microsculpture from a specimen from Hillersholmen (Figure 16 F). Scale bar $=200 \mu \mathrm{m}$.

Figure 15. Raphitoma linearis. A specimen photographed alive in a petri-dish. From Bukkasundet, 60¹4'N, c. 12 m. $5.5 \mathrm{~mm}$. 
three times the width of the cords. Tubercles where cords cross axial ribs form rather sharp 'points'. Aperture elongated oval drawn out into moderately long siphonal canal. Sculpture on siphonal canal of wide spiral cords crossed by equally wide ribs. A shallow anal sinus in outer lip near suture. Microsculpture (Figures 1A, 2A and 14) of contiguous, irregular granules, not separate pustules as in $R$. aequalis and $R$. obesa $\mathrm{n}$.sp. Protoconch (Figures $3 \mathrm{~A}$ and 14) 3.5 to 4 whorls, narrow, W/L: 0.96, apical angle $43.5^{\circ}-46.3^{\circ}$, with a coarse decussate grid and a distinct keel at transition to teleoconch. Protoconch colour usually dark purplish brown closest to the teleoconch and opaque yellowish white at the apex, rarely much lighter throughout.

Variability. Specimens from the Mediterranean apparently have pure white ground colour with fine brown spiral lines (see Remarks below). One of my specimens approach this colour, viz. the one illustrated in Figure 14 and 16C. This specimen with most contrast (yellowish white against dark brown) was the most recently caught, having been kept in ethanol for only a week, others have been stored in ethanol for some 40 years before being photographed. The colour variation is partly
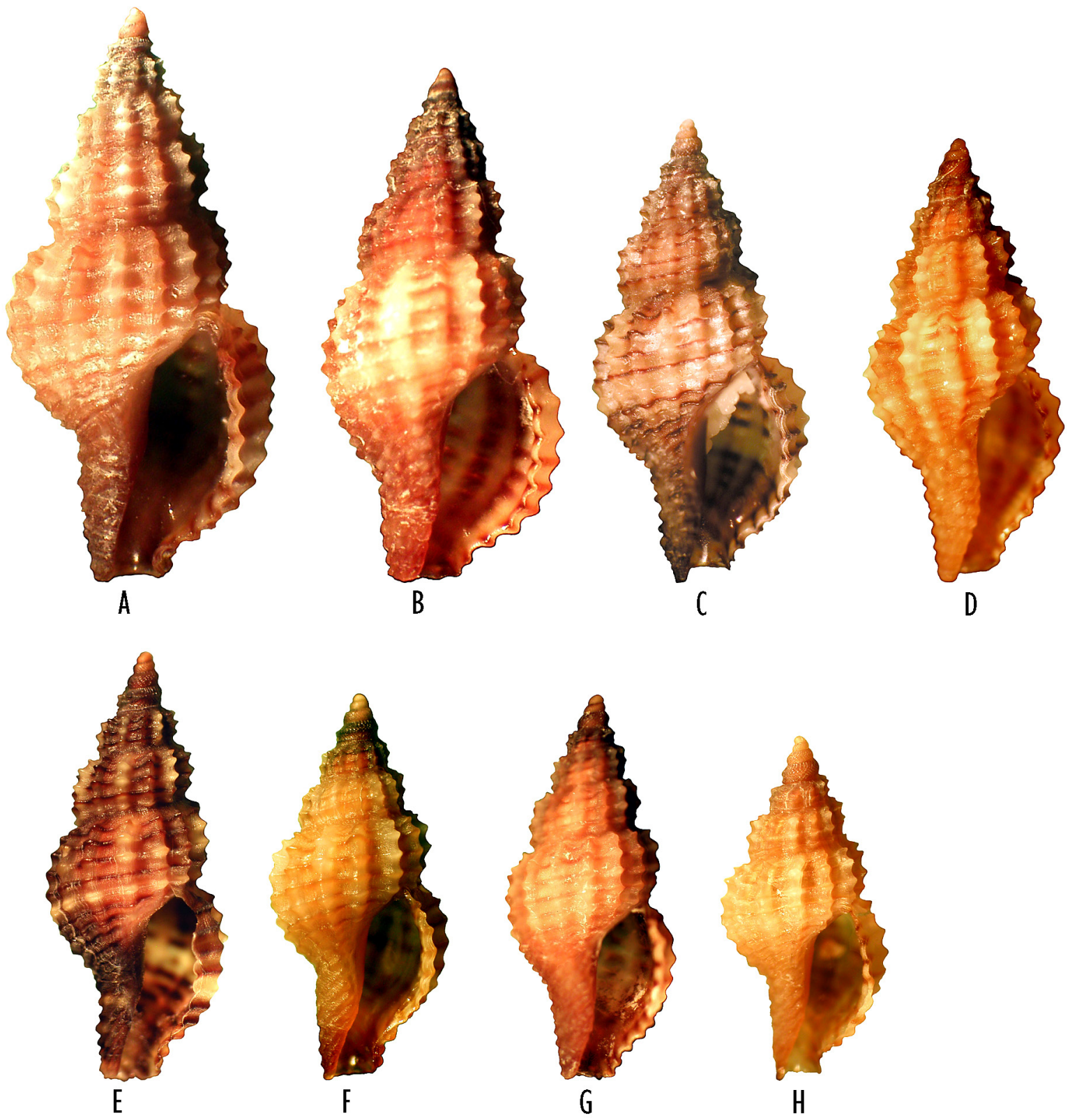

Figure 16. Eight specimens of Raphitoma linearis showing variability of the shell. Specimens to scale, the largest $7.4 \mathrm{~mm}$. A and $\mathrm{H}$. Bukkasundet, 60¹4'N, 14 m (1966); B, D and G. Hillersholmen, 60¹8'N, 8 m (1967); C and E. Bukkasundet, 60¹4'N, c. 12 m (2007); F. Hillersholmen, $60^{\circ} 18^{\prime} \mathrm{N}, 8 \mathrm{~m}(1969)$. 


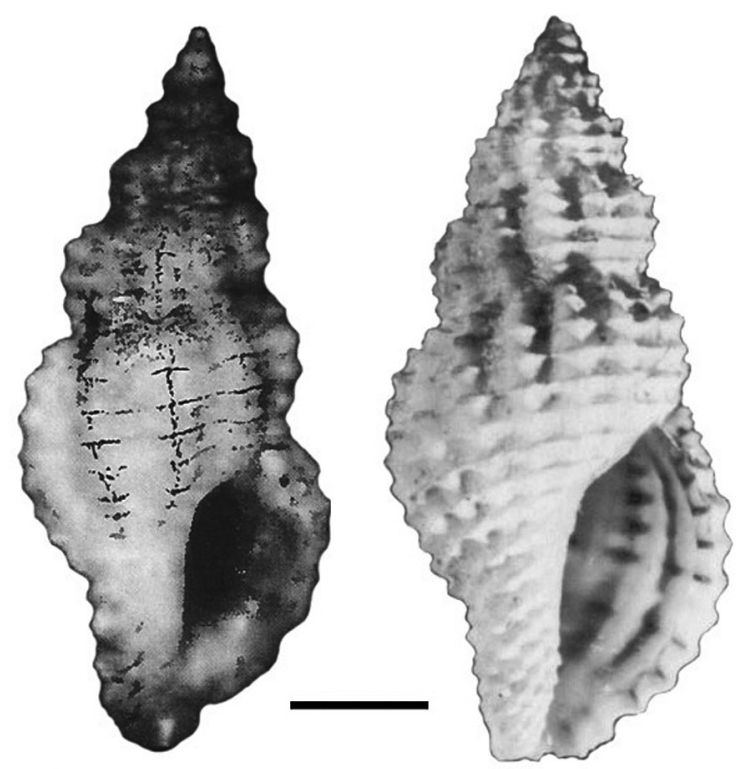

Figure 17. Lectotype of Murex linearis, left (from Rolán et al 1998) and holotype of Cenodagreutes coccyginus (from Smith 1967a). Both specimens $5.5 \mathrm{~mm}$.

due to the effect of ethanol. In some of the stored specimens, however, both the ground colour and the spiral cords (yellowish brown) are much lighter than the majority. Usually the brown spiral cords are darker than in $R$. aequalis (e.g. Figure $16 \mathrm{E}$ also photographed alive, Figure 15) but with a large overlap.

The specimen studied alive (Figure 15) had foot and siphon uniformly white. The specimen was rather lively, frequently and swiftly changing directions while crawling. The siphon in front of the siphonal canal is long, tubular and slightly narrower in front. The foot is deeply embayed in the mid line, and has recurved anterolateral corners. As seen in Figure 15, the foot is very flexible and aids the animal to rapidly turn around if placed upside down on the substrate.

Distribution. Recorded from Morocco and the Canary Islands to northern Norway, including the entire Mediterranean (Cachia et al. 2001, Öztürk et al. 2004, Giannuzzi-Savelli, pers. comm, and G.O. Sars 1878). The North European records in the literature (Friele 1874, G.O. Sars 1878, Norman 1879, Fretter \& Graham 1985, Høisæter 1986, Smith \& Heppel 1991) are just as likely to be the more common $R$. aequalis than $R$. linearis (see above). The material I have seen, is from the Grimstad area on the Skagerrak coast and north to Raunefjorden south of Bergen $\left(60^{\circ} 15^{\prime} \mathrm{N}\right)$. There are no verified records north of Sognefjorden, except for a single doubtful shell from $67^{\circ} \mathrm{N}$.

Remarks. Norwegian specimens of $R$. linearis are morphologically similar to $R$. aequalis, and the two are often hard to tell apart. The best way to separate $R$. linearis from $R$. aequalis is the microsculpture (see above), the slightly more 'spiky' macrosculpture, and the knobby spirals on the outer siphonal canal as opposed to the smooth spirals in $R$. aequalis. Most specimens have a very dark purplish colour in the transition whorls between protoconch and teleoconch. A further argument for the specific separation of $R$. aequalis and R. linearis is the observation of E.H. Smith (1967a, b) that there are several differences in the internal organs (alimentary tract and reproductive system) between Cenodagreutes aethus and $C$. coccyginus, here regarded as synoms for $R$. aequalis and $R$. linearis respectively. The morphological data indicate that $R$. linearis and $R$. aequalis are closely related. The fact that both species lack radula, as opposed to several other species of Raphitoma s.l., e.g. R. purpurea and R. concinna, supports the hypothesis of a closer relationship between these two species than of any of them to either $R$. purpurea or $R$. concinna.

\section{Raphitoma purpurea (Montagu, 1803)}

Figures 18 - 20

Murex purpureus Montagu, 1803:260, Tab. 9, f. 2

Defrancia purpurea (Montagu, 1803) - Jeffreys 1867; Friele 1874; Norman 1879

Defrancia purpurea var. oblonga Jeffreys 1867:374 (?)

Clathurella purpurea, Mont. - G.O. Sars 1878

Philbertia purpurea (Montagu, 1803) - Monterosato 1884;

Hubendick \& Warén 1976; Høisæter 1986

Raphitoma purpurea (Montagu, 1803) - Rolán 1983; Fretter \& Graham 1985; Graham 1988; Sabelli et al. 1990; Smith \& Heppell 1991; Heppell et al. 1997; Cachia et al. 2001; Høisæter 2009

Type material. Lectotype and two paralectotypes, designated by Rolán et al. (1998), BMNH 1995089. (Figure 20C). Holotype of Defrancia purpurea var. oblonga, USNM 190029 (Warén 1980, Pusateri et al. 2012) (Figure 20B).

Type locality. Salcombe Bay, Devon, England.

Material examined. Six empty shells from: Hjartøysundet, Bodø, $67^{\circ} 17.5^{\prime} \mathrm{N}, 75-64 \mathrm{~m}$; W of Svinøy, $64^{\circ} 55^{\circ} \mathrm{N}, 11^{\circ} 22^{\prime} \mathrm{E}, 175-$ $20 \mathrm{~m}$, shell sand; Lamholmen north of Gjerdingen, 64 $57.30^{\circ}$ $\mathrm{N}, 11^{\circ} 25^{\prime} \mathrm{E}, 80-30 \mathrm{~m}$; Outer part of Foldafjorden $64^{\circ} 40.20^{\prime} \mathrm{N}$, $1^{\circ} 07.30^{\prime} \mathrm{E}, 60-20 \mathrm{~m}$; Near Lillesand, $58^{\circ} 15^{\prime} \mathrm{N}, 08^{\circ} 26^{\prime} \mathrm{E}, 8 \mathrm{~m}$, and a shell from Bergen (ZMBN 28685).

Description. (Based mainly on an, immature, specimen from Hjartøysundet, Figure 18, with additional details from Fretter \& Graham 1985). Shell long and narrow (height from 2.26 to 2.35 times the diameter), with up to 12 whorls at 20 $\mathrm{mm}$ height. No shells longer than $c .12 \mathrm{~mm}$ so far found in Norwegian waters. Shell colour impossible to ascertain from my empty shells, but stated to be brownish to purplish with scattered whitish specs and ribs (see shell from Bretagne, Figure 20A). Sculpture of numerous axial ribs and almost equally strong spiral cords. 'Valleys' between spiral cords only slightly wider than the cords. Five to six fully developed spiral cords on penultimate whorl, but with secondary, narrower cords between the uppermost primary spirals. Body whorl 65 to 66 

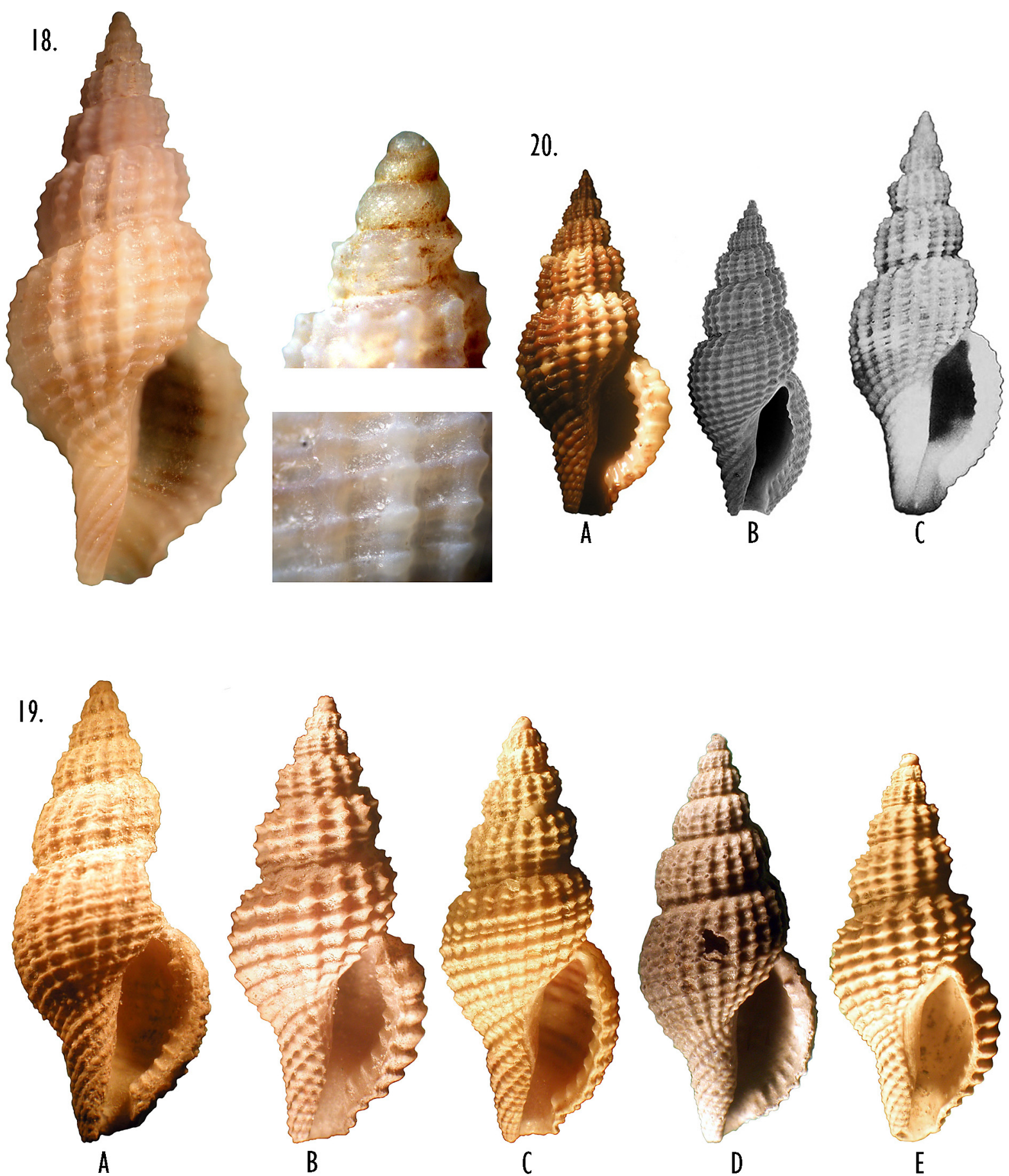

Figure 18. Raphitoma purpurea. $7.1 \mathrm{~mm}$ long. From Hjartøysundet, $67^{\circ} 17.5^{`} \mathrm{~N}, 75-64 \mathrm{~m}$.

Figure 19. Five shells of Raphitoma purpurea. Shells to scale, the largest $11.25 \mathrm{~mm}$. A. Bergen (ZMBN 28685); B. Foldafjorden, between

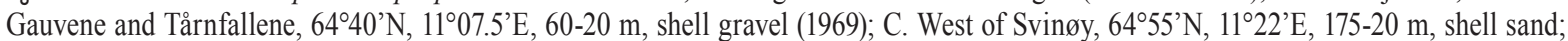
D. Lamholmen, North of Gjerdingen $64^{\circ} 57.5^{\prime} \mathrm{N}, 1^{\circ} 25^{\prime} \mathrm{E}, 30 \mathrm{~m}$ (1969); E. Kallnes, Lillesand, 58¹5'N, 08²6'E, 8 m (1988).

Figure 20. Raphitoma purpurea. A. Specimen from Pointe d'Arcouest, Bretagne, France, low tide, 11.8 mm; B. Defrancia purpurea var. oblonga Jeffreys, 1867, holotype, Jersey (original photo of holotype USNM 190029), $10.6 \mathrm{~mm}$; C. Murex purpureus, lectotype, Salcombe Bay, Devon (BMNH 1995089), 15.1 mm (from Rolán et al. 1998, size corrected by Giannuzzi Savelli pers. comm.). 
$\%$ of total height. Siphonal canal short and wide. Sculpture on siphonal canal of thickened spirals sectioned into numerous nodules by the axial ribs. Outer lip thickened and (usually) with eleven coarse denticles on the inside. Fairly deep and narrow anal sinus. Protoconch (only conserved in the specimen from Hjartøysundet, Figure 18) short and narrow, with three whorls and apical angle $40^{\circ}$ to $45^{\circ}$. Protoconch W/L: 0.97. The protoconch is smaller than in any of the other species found in Norwegian waters. Microsculpture hard to tell from old, worn shells, but appear to consist of rather coarse granulation (Figure 18).

Variability. The six shells seen (Figure 19) have a fairly constant morphology. The denticulation inside the thickened outer lip is present only in mature shells, as is the secondary spiral cords on body whorl.

Distribution. In older Norwegian literature reported as rare around Bergen (M. Sars according to Jeffreys 1867, Friele 1874, Norman 1879, Hubendick \& Warén 1976), and from Kristiansund (Danielssen according to Jeffreys 1867). In my material three empty (old) shells from $65^{\circ} \mathrm{N}$, and one fresh shell from around $67^{\circ} \mathrm{N}$, in addition to a single shell from the Skagerrak coast. Also reported from Bohuslän in Sweden (Malm according to Jeffreys 1867). Around the British Isles, it occurs everywhere except on the North Sea coast. Most common in the southern part, but also found occasionally around Shetland (Seaward 1990). Elsewhere found from the Atlantic coast of France and southwards to the Strait of Gibraltar. According to Cachia et al. (2001) also in the Mediterranean at least as far east as Malta, although Monterosato (1884) and van Aartsen et al. (1984) claim that it does not occur in the Mediterranean. Not included in newer check-lists of Mollusca from the Mediterranean.

Remarks. Characterized by thickened outer lip with heavy denticulation, short and narrow protoconch and very prominent tubercles where axial ribs are crossed by spiral costae. The species is reported to reach $23 \mathrm{~mm}$ in length (Rolán 1983), so the shells in my material are small, although the heavy teeth on the inner lip on all but one of the shells seen, indicate that they are mature. Jeffreys (1867:374) described a 'variety', Defrancia purpurea var. oblonga from the Channel Islands (Figure 20B above) which is distributed along the southern and western coast of the British Isles as well as the Atlantic coast of France. The 'variety' is accepted as a valid species, Raphitoma oblonga (Jeffreys, 1867) by Pusateri et al. 2012. Compared with the sympatric form of $R$. purpurea (Figure 20A) it is less solid and turreted and with significantly more ribs and cords. According to Jeffreys (1867:374) the colour and other characteristics of the soft parts are different for the two species. $R$. oblonga has not been recorded from Norwegian waters.

\section{Subgenus Leufroyia Monterosato, 1884}

Type species. Pleurotoma leufroyi Michaud, 1828, S.D. Crosse (1885) (fide Pusateri et al. 2012). Recent, Mediterranean coast of France.

Diagnosis. Raphitomids with broad, wavy axial ribs; dense and numerous, low spiral cords (three to four on adapical teleoconch whorl). Microsculpture of dense, rather conspicuous growth lines, or rugae, no granules or pustules. Protoconch with three or four whorls, the apical one wider (at c. 220 to $250 \mu \mathrm{m}$ diameter) and lower than in the 'multispiral' species in the Raphitoma group, and with a weak, incipient rounded keel for a quarter of a whorl at the transition to the teleoconch. The characteristic cancellated sculpture covers $1 \frac{1}{2}$ of these whorls, while the apical $1 \frac{1}{2}$ whorls are covered by eight to nine punctuated spiral striae.

Remarks. Leufroyia was introduced by Monterosato (1884) as one of two genera, the other being Cordieria (Monterosato, 1884), encompassing Raphitoma sensu Bouchet \& Gofas 2015.The diagnosis was brief ("Gruppo ben distinto ad anfratti rigonfi, costati, spiralmente striati; bocca ingrossata internamente, levigata, senza denti nè solchi") ["Distinct group with convex whorls, with costae, spirally striated; aperture inflated, internally smooth, without teeth or grooves"]. Most of these descriptive terms could be applied to many other species of Raphitoma s.l. However the group was well distinguished by the three species included, $R$. leufroyi, $R$. concinna (Scacchi, 1836) and R. erronea (Monterosato, 1884). Later authors have used Leufroyia both as a genus and a subgenus, but have apparently had difficulties in specifying the morphological characters distinguishing the taxon. Defined by van Aartsen et al. (1984:91) as: “...species with noncarinate, but still diagonally cancellate protoconch whorls,...”; by Campani (1999): "Protoconch multispiral of four whorls, with diagonally cancellated sculpture on at least the two lower whorls, not carinate but regularly rounded." [translated from Italian]; and by Cachia et al. (2001:63): "Protoconch consisting of three rounded whorls, first blunt, last two cancellated, rather oblique ribs on body whorl". In my opinion (based on the Norwegian material), the main diagnostic morphological characters are the details of the (micro)sculpture as specified above. The protoconch is certainly different from other Raphitoma species, but the number of whorls and the presence or absence of a terminal keel might be of specific rather than generic value, as evidenced by the SEM-photo in Campani (1999) of a protoconch belonging to $R$. leufroyi which is very similar to my $R$. concinna, but with four rather than three whorls, and no visible keel.

A single Norwegian species is referable to the subgenus.

\section{Raphitoma (Leufroyia) concinna (Scacchi, 1836)}

Figures 2F, 3D and $21-23$

Pleurotoma concinna Scacchi, 1836:12, Figure 18 (fide Cretella et al. 2005)

Raphitoma concinna (Scacchi, 1836) - Rolán 1983; Sabelli et al. 1990; Öztürk et al. 2004; Høisæter 2009; CLEMAM 
2014; Gofas 2015bDefrancia Leufroyi Michaud - Jeffreys 1867; Friele 1874; Norman 1879 non Pleurotoma leufroyi Michaud, 1828:121

Clathurella Leufroyi, Mich. - G.O. Sars 1878

Philbertia leufroyi (Michaud) - Hubendick \& Warén 1976; Høisæter 1986

Raphitoma leufroyi (Michaud, 1828) - Fretter \& Graham 1985; Graham 1988; Cachia et al. 2001

Fusus Boothi Brown in J. Smith, 1839:98

Leufroyia Boothii, Brown - Monterosato 1884

Raphitoma boothii (Brown in Smith, 1839) - Olsen 1994

Raphitoma (Leufroyia) boothii (Brown in Smith, 1839) van Aartsen et al. 1984; Smith \& Heppell 1991; Heppell et al. 1997

Type material. Presumed lost (Cretella et al. 2005)

Type locality. "In sinu Neapolitano et Tarentino parum frequens" (Cretella et al. 2005).

Material examined. Sixty-two specimens from 31 stations from $c .58^{\circ} \mathrm{N}$ to $61^{\circ} \mathrm{N}$ on the coast of Norway. A single juvenile from Hjartøysundet, Bodø, Nordland county, $67^{\circ} 10.7^{\prime} \mathrm{N}$, $14^{\circ} 20.3^{\prime} \mathrm{E}, 35 \mathrm{~m}$, coarse shell gravel.

Description. Based mainly on a specimen from Hillersholmen (Figure 21), $10.5 \times 5.2 \mathrm{~mm}$ ) and one from O-sundet (Figure 23C), 11.2 x $4.6 \mathrm{~mm}$. Maximum size of those measured, $12.1 \mathrm{~mm}$ (specimen from O-sundet, Figure 23A). Shell thick and opaque; height 2.04 to 2.45 times the diameter (for shells longer than $9.5 \mathrm{~mm}$ ), thus extremely variable (compare Figure 21 with Figure 23C). Body whorl 64-72 \% (usually between 70 and $72 \%$ ) of total shell height. Shell colour variable, from dark brown to bright yellow, usually with dark spiral cords on a light-coloured background. Teleoconch whorls five (for 11-12 $\mathrm{mm}$ long specimens), convex with deep and distinct suture. Adapical teleoconch whorl 775-873 $\mu \mathrm{m}$. Sculpture of numerous wide and dense axial ribs crossed by wide and low spiral cords, 12 on penultimate whorl. Distance between cords almost twice the width of the cord. Tubercles where cords cross axial ribs, low transverse swellings on ribs. Axial ribs fading out towards base, not discernible on siphonal canal. In some large shells hardly any ribs on body whorl. Siphonal canal of varying length usually short (but compare Figure 23F with 26G). Shallow and wide anal sinus in outer lip near suture. Outer lip thickened but not denticulated. Microsculpture (Figures $2 \mathrm{~F}$ and 21) of growth lines and irregular rugae, never isolated pustules or granules. Protoconch (Figures 3D and 21) of three whorls, nine spiral rows of isolated 'points' on the apical $1 \frac{1}{2}$ whorl, the rest with diagonal diamonds as in other 'multispiral' species of Raphitoma. Diameter of apical whorl 225-250 $\mu \mathrm{m}$. Apical angle $48^{\circ}-54.5^{\circ}$ (usually more than $50^{\circ}$ ). Protoconch W/L: 1.1 . Protoconch colour same as teleoconch colour, usually with white apical tip (Figure 21). Radula illustrated in G.O. Sars (1878:Tab. VIII, Figure 3).

Variability. A most variable species (Figure 23). Colour from dark brown to yellow, younger shells usually with dark brown cords on light background (e.g. Figure 23G). Wide variation in the $\mathrm{H} / \mathrm{D}$ ratio and the relative length of the siphonal canal. A specimen studied alive (Figure 22) was, as opposed to the other three species observed alive, reluctant to extend its foot much out of the aperture. The colour appears to be clear, translucent white.

Distribution. In Norway known from near Bodø, $67^{\circ} 11^{\prime} \mathrm{N}$, $14^{\circ} 20^{\prime} \mathrm{E}$, and southwards. Rare north of Hordaland county, but fairly common in shallow water on the western coast and apparently also on the Skagerrak coast. The northern distributional limit is based on a single juvenile in the material of Per Wikander from 1976, the former northern limit was Trondheimsfjorden (around $64^{\circ} \mathrm{N}$ ). Seven specimens from the Skagerrak coast (1972 to 1989) in the material of Per Wikander. According to Olsen (1994) seven records from Oslofjorden in
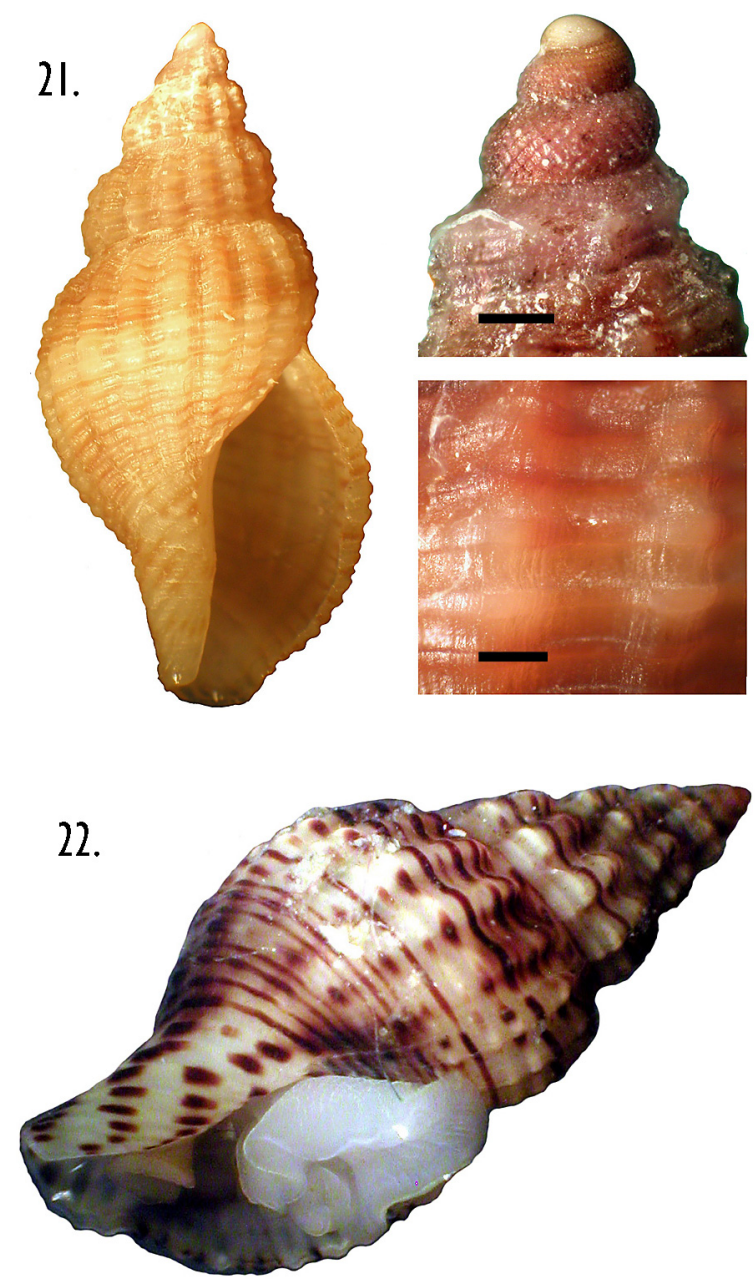

Figure 2l. Raphitoma concinna. $10.5 \mathrm{~mm}$ long. Specimen from Hillersholmen, $60^{\circ} 18^{\prime} \mathrm{N}, 8 \mathrm{~m}$ (1969). Protoconch from specimen in Figure 23H. Microsculpture from specimen in Figure 23J. Scale bars $=200 \mu \mathrm{m}$.

Figure 22. Raphitoma concinna. A specimen (same as in Figure 23G) photographed alive in a petri-dish. 
1991-1992. In Oslofjorden only known from Drøbak in earlier literature. Reported also from Bohuslän in western Sweden (Hubendick \& Warén 1976), and from the Kola inlet on the Murman coast of Russia (Nekhaev 2014:102, Fig. 10A), (this latter record however, is based on an empty shell of what appears to be Raphitoma obesa n. sp., see above). Further south in Europe it is common in British waters (as Raphitoma leufroyi - Jeffreys 1867, Fretter \& Graham 1985, Seaward 1990), and has been reported from the Atlantic coast of France and Spain (Rolán 1983). The species is found in the Mediterranean (described from the Bay of Naples) but according to Cachia et al. (2001) it is rare in Maltese waters. Reported from Cyprus in the eastern Mediterranean (Öztürk et al. 2004). Not reported by van Aartsen et al. (1984) from the Bay of Algeciras outside

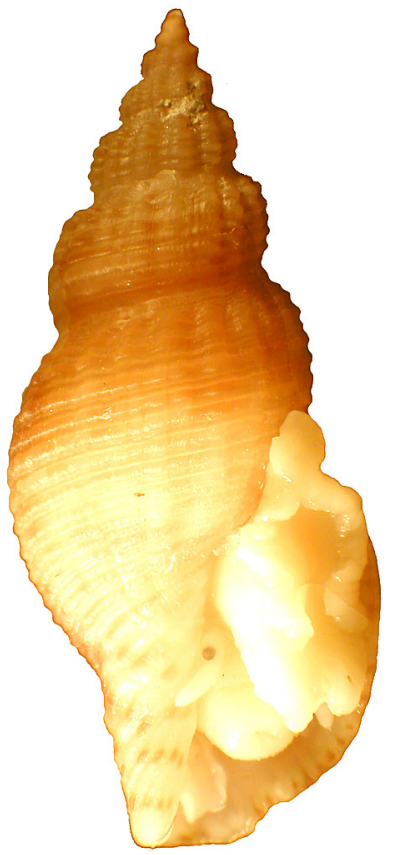

A

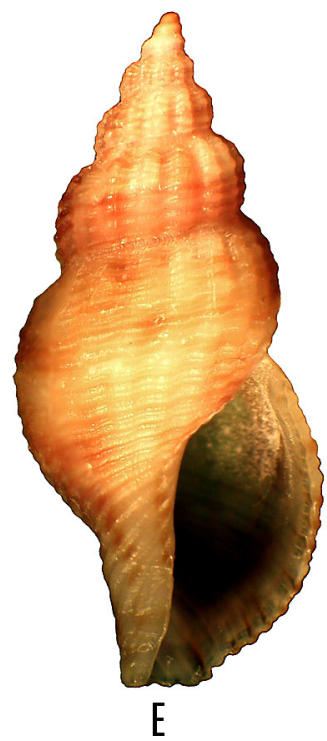

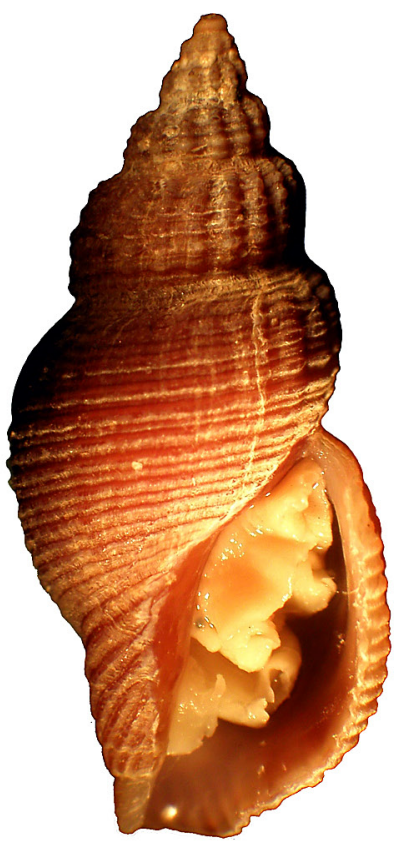

B

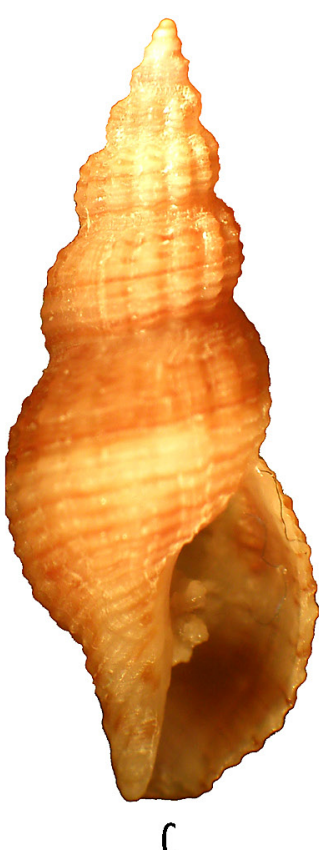

C

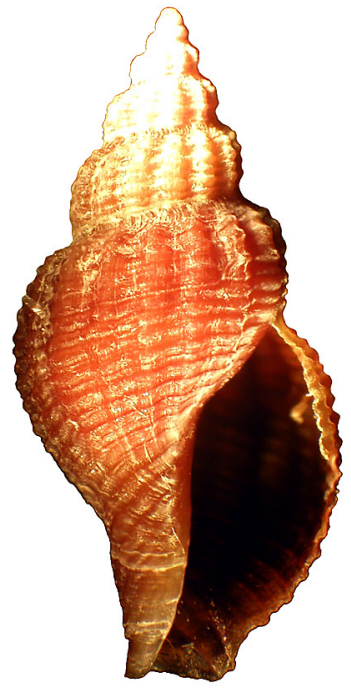

D
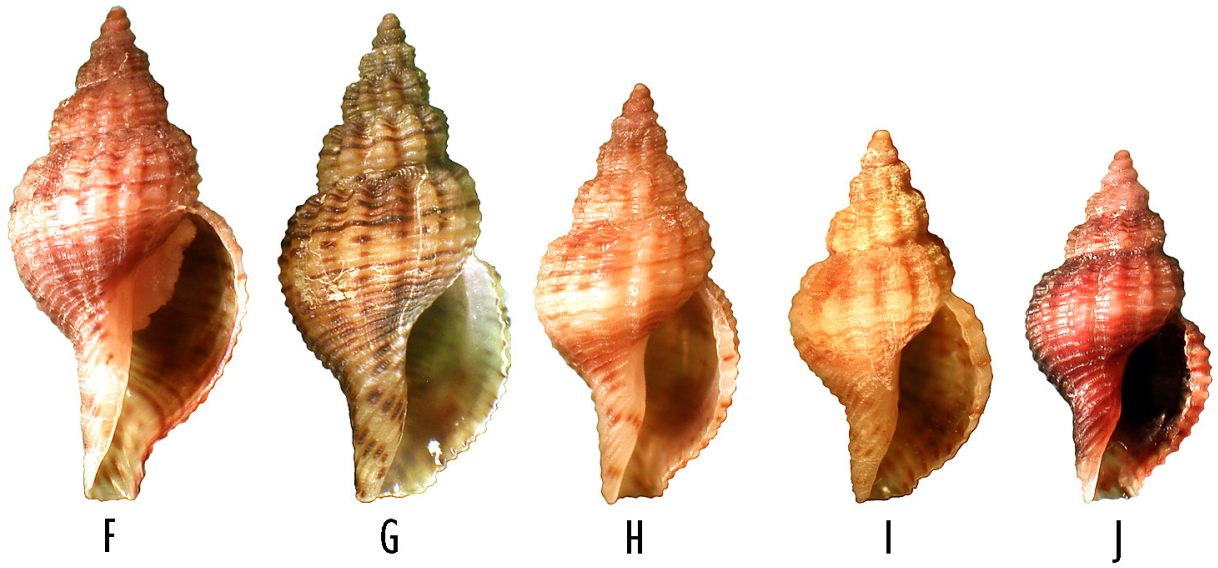

Figure 23. Ten specimens of Raphitoma concinna. Specimens to scale, the largest $12.1 \mathrm{~mm}$ long. A, C and E. O-sundet $60^{\circ} 35^{\prime} \mathrm{N}, 15-20$ m (1969); B. Hillersholmen, 60¹8’N, 8 m (1967); D. Hillersholmen, 60¹8’N, 8 m (1968); F. Svelgen, 60²7’N, 20-10 m (2010); G. Bukkasundet, $60^{\circ} 14.23^{\prime} \mathrm{N}, 05^{\circ} 12.33^{\prime} \mathrm{E}$, c. 12 m (2007); H. Bukken, 60¹4.23’N, 05¹2.33'E, 15 m (2007); I. Hillersholmen, 60¹8'N, 8 m (1969); J. Bukkasundet, 60¹4’N, 05¹2’E, 12-15 m (2007). 
the Strait of Gibraltar.

Remarks. Which name to use for this common species in the North Atlantic has been highly disputed. The North Atlantic taxon was originally named $R$. boothi (J. Smith, 1839), presumably without any comparison with Mediterranean relatives. Jeffreys (1867) compared British specimens with Mediterranean specimens of $R$. leufroyi and $R$. concinna. He concluded that the two were synonyms and that neither could be distinguished from $R$. boothi. R. leufroyi being the oldest should thus be the name to use. This decision has been adopted by most North European authors, and the species is listed as R. leufroyi in most check-lists from the region (e.g. Høisæter 1986, Graham 1988, Seaward 1990). However, authors from the Mediterranean region have not necessarily agreed. Thus Monterosato (1884) explicitly considered $R$. boothi to be different from $R$. leufroyi, and $R$. concinna to be a species distinct from both. In his opinion the two latter are confined to the Mediterranean, whereas the former is found only in the North Atlantic, outside the Mediterranean. Both $R$. concinna and $R$. leufroyi were reported from Ria de Vigo on the northwestern coast of Spain by Rolán (1983), R. concinna being by far the most common of the two. Van Aartsen et al. (1984) also considered all three to be specifically distinct, separating $R$. boothi from $R$. leufroyi. They did not compare $R$. concinna with $R$. boothi. Cachia et al. (2001) do not mention $R$. boothi, but report both $R$. concinna and $R$. leufroyi from Maltese waters. Warén (pers. comm.) has not been able to find any morphological differences between the Mediterranean R. concinna and specimens from the North Atlantic. Recently Gofas (2015b) and CLEMAM (2015) have accepted $R$. boothi as a synonym of $R$. concinna, and the latter should thus be the valid name for the North Atlantic species. According to descriptions and available illustrations (e.g. van Aartsen et al. 1984; Cachia et al. 2001 and Rolán 2005) $R$. leufroyi has a characteristic colour pattern and very prominent axial ribs, not found in Norwegian material. I follow the recent consensus and regard all members of the subgenus Leufroyia from the North Atlantic outside the Mediterranean to belong to R. concinna (Scacchi, 1836), and R. boothi (J. Smith, 1839) to be a subjective synonym of $R$. concinna.

\section{DISCUSSION}

Of the six species of Raphitoma described in the review, only three are relatively common in Norwegian inshore waters, and only one is common in waters north of c. $64^{\circ} \mathrm{N}$. This review does not, however, pretend to exhaust the diversity of Norwegian members of the genus. Several more or less well preserved shells from the Skagerrak coast $\left(58^{\circ}-59^{\circ} \mathrm{N}\right)$ indicate that the list of Norwegian species is longer than the six species named above. Most of the shells not included belong in the $R$. linearis/R. aequalis/R. obesa group, but also a shell with clear affinity to the $R$. purpurea group but in too bad condition to be properly described, points towards a larger species pool than suspected so far. In addition the species named $R$. cf. echinata above will most likely be included in future reviews of the Norwegian Raphitoma fauna. Part of the reason for not attempting to formally increase the number of species belonging to the Norwegian fauna is the lack of live caught specimens.

Colour pattern is often the first character used in identifying a shell, but even with living specimens this might be misleading because of variability. In shells long dead or stored in ethanol, the colours are rapidly fading. While the living snails show a distinct colour pattern with brightly coloured spiral cords (see e.g. Figure $11 \mathrm{D}$ and G, and Figure $16 \mathrm{C}$ and $\mathrm{E}$ ), the shells having been stored for several years before being photographed, are usually more or less homogeneous in colour, e.g. uniformly yellowish or whitish (e.g. Figures 11A and B, and 16D and F). In addition to the shell colour pattern, soft part morphology and behaviour (Figures 5, 9, 15, and 22) are promising areas for further study. So far a single specimen of each of four species have been studied. The striking contrast in behaviour between the specimens of $R$. linearis and $R$. aequalis strongly support that these are separate species. Thus the specimen of $R$. aequalis (Figure 9) turned out to be rather sedate, moving slowly in a preferred direction. The specimen of $R$. linearis (Figure 15) was more 'vivacious', frequently and swiftly changing directions while crawling. In addition the part of the siphon of $R$. linearis in front of the siphonal canal is long, tubular and slightly narrower in front, while that of of $R$. aequalis is apparently comparatively wider but extend only a fraction of a $\mathrm{mm}$ in front of the canal when the animal is crawling. The foot of $R$. linearis (and presumably also the other three species) is deeply embayed in the mid-line, and has recurved anterolateral corners. As seen in Figure 15, the foot of $R$. linearis is very flexible and helps the animal to rapidly turn around if placed upside down on the substrate. No similar flexibility was observed in any of the other specimens observed. The siphon of $R$. maculosaalso extends a long distance in front of the siphonal canal while the animal is crawling. It is somewhat bulb-shaped in front, and have 30 to 40 distinct white spots on a slightly grayish background colour. White spots were distributed liberally over all visible parts of the head-foot complex in this specimen, as have been observed in other species of the $R$. echinata species complex.

Protoconchs, macrosculpture, microsculpture and relative length of the siphonal canal, are useful, but variable characters for distinguishing between species. However, all of these are hard to describe in a way that is helpful for species identification. The microsculpture (Figures 1 and 2) may be the most useful of these, but sometimes even that one is hard to interprete.

The transition zone between protoconch and teleoconch is sometimes a useful morphological detail to confirm the determination of a doubtful specimen. This is especially useful for distinguishing between $R$. aequalis and $R$. linearis. The latter species has two whorls of a dark purplish-brown colour between whorls of a much lighter hue. This colour difference is visible even in specimens stored for a long time in ethanol 
(see e.g. Figure 16F). The protoconch and transition zone of $R$. aequalis on the other hand has an almost uniform milkchocolate colour.

Ideally types, or at least topotypes, should be studied in order to verify the names of the species treated. No type material or other extralimital museum material has been studied for this review, but the fact that the species has been described from British material and are easily distinguished from sympatric congeners, is in my opinion sufficient reason for adopting the well-known and already accepted species names: $R$. linearis, $R$. aequalis and $R$. purpurea for the Norwegian species. This group is sorely in need of DNA-based phylogenies, and when DNA-based analyses are produced, it might very well turn out that some Scandinavian species are different from their British counterparts. Available evidence indicates that most Mediterranean species of the genus are confined to the Mediterranean, but species of the $R$. linearis/ aequalis group as well as the $R$. leufroyi-groups are exceptions being found along the East Atlantic coast both south of and north of the Mediterranean. The acceptance of $R$. concinna as the name for Norwegian member of the $R$. leufroyi-group is partly based on this hypothesis.

The material studied for this review is practically all the material ever collected from inshore Norwegian waters. A limited amount of material from deeper waters on the shelf or outer coast are listed in the MOD database (Environmental Monitoring Database [MOD https:/projects.dnvgl.com/MOD/ Default.aspx?TOOL=ArtUt]). Most of this material is sorted from grab-hauls from 100 to $165 \mathrm{~m}$ depth, in the North Sea or on the western slope of the Norwegian Trench and thus outside the geographic area here considered part of the Norwegian faunal realm.

As hinted to above, strict enforcement of the priority rules concerning the family name Raphitomidae, is not optimal. The continued use of Daphnellidae would have led to fewer taxonomic problems, as Daphnella is based on a well-known Recent species.

Ideally, genera should be based on a phylogenetic analysis. The genera in common use today are mostly from a prephylogenetic era, and need confirmation from DNA-based analyses. As it is rather impractical to discard all names not yet based on a sound phylogenetic analysis, I find it acceptable to use Leufroyia as the name of a subgenus, as this is well supported by shell morphology, and has been adopted by most Mediterranean authors of check-lists. Most likely the heterogeneous subgenus Raphitoma will be split into several genus group taxa in the future, one for the $R$. linearis-group, one for the R. purpurea-group and one for the R. echinatagroup. Both the micro- and the macro-sculpture are sufficiently distinct in each of these groups to support such a splitting. E.H. Smith (1967a) argues that the lack of radula (and other peculiarities in the foregut anatomy) in at least two species from the Northeast Atlantic, justifies the erection of a separate genus, Cenodagreutes. The two species, from western Scotland, he described as new, he surprisingly did not compare with members of the $R$. linearis/R. aequalis complex. However, as is apparent from his detailed descriptions of shell characters as well as his holotype photographs (see Figures 10 and 17 above), $C$. aethus is most likely a synonym of $R$. aequalis, and $C$. coccyginus of $R$. linearis. It is highly unlikely that two species not previously described should be found sympatrically with the common look-alikes in 1967. This synonymy has been accepted in several recent check-lists (e.g. CLEMAM 2015, WoRMS 2015). R. linearis (or R. aequalis) was already in the 1870-ties shown to lack a radula (G.O. Sars 1878:348). G.O. Sars regarded the lack of radula to be of generic value, and suggested that $R$. aequalis (as $R$. linearis) should be generically separated from $R$. concinna (as $R$. leufroyi). More recently it has been extensively documented that species in the $R$. linearis complex lack radula (e.g. Sheridan et al. 1973 and Fedosov 2008). Neither G.O. Sars (1878) nor Fedosov (2008) suggested an alternative genus name for this subgroup of Raphitoma. Monterosato (1884) suggested Cirillia as name for this group, but did not refer to the lack of radula as a diagnostic character. However, Cirillia is preoccupied, and if the $R$. linearis complex is accepted as a genus-group taxon, it needs another name. Lineotoma Nordsieck (1977) has been suggested as a replacement name, but Cenodagreutes is older and might thus be the valid name for this group if DNA-based phylogenetic analyses should confirm that they constitute a clade of generic rank.

\section{ACKNOWLEDGEMENTS}

I am grateful to Per Johannessen of SAM/UNIFOB and David Osca of Museo Nacional de Ciencias Naturales, Madrid, but especially Per Bie Wikander from Grimstad, for providing important material. Louise Lindblom, Kenneth Meland and Solveig Thorkildsen of the Biodiversity Group of the Department of Biology, University of Bergen, for trying to tease out some DNA secrets of part of the material for an earlier version of the ms. Jon Anders Kongsrud at the University Museum of Bergen Natural History Collections is thanked for loan of museum material. Jean-Paul Kreps from Royal Belgian Institute for Natural Sciences donated specimens of $R$. purpurea from Bretagne. The late Christoffer Schander kindly read an early version and offered helpful comments. Last but not least thanks to Anders Warén for helping with literature and good advice. Riccardo Giannuzzi-Savelli and an anonymous referee provided much needed resistance, and forced me to thoroughly reanalyze my conclusions. Giannuzzi-Savelli has given much helpful advice in addition to his review of the ms.

\section{REFERENCES}

Aartsen JJ van, Menkhorst HP, Gittenberger E. 1984. The marine Mollusca of the Bay of Algeciras Spain with general notes on 
Mitrella, Marginellidae and Turridae. Basteria Supplement No. 2:1-135.

Bellardi L. 1847. Monografia delle Pleurotome Fossili del Piemonte. Pp 122, Torino.

Bellardi A. (sic!) 1875. Novae pleurotomidarum Pedemontii et Liguriae fossilium dispositionis prodromus. Bullettino della Societá Malacologica Italiana 1(1):16-24. (Not seen).

Bouchet P. 1990. Turrid genera and mode of development. The use and abuse of Protoconch Morphology. Malacologia 32:69-77.

Bouchet P. 2015. Raphitomidae Bellardi, 1875. Accessed through: World Register of Marine Species at http://www.marinespecies. org/aphia.php? $\mathrm{p}=$ taxdetails\&id=153879 on 2015-01-19

Bouchet P, Gofas S. 2015. Raphitoma Bellardi 1847. Accessed through: World Register of Marine Species at http:/www. marinespecies.org/aphia.php? $p=$ taxdetails\&id=137829 on 2015 01-19.

Bouchet P, Kantor Y, Sysoev A, Puillandre N. 2011. A new operational classification of the Conoidea (Gastropoda). Journal of Molluscan Studies 77:273-308. doi: 10.1093/mollus/eyr017

Bouchet P, Rocroi J-P. 2005. Classification and Nomenclator of Gastropod Families. Malacologia 47:1-397.

Bouchet P, Warén A. 1980. Revision of the North-East Atlantic, Bathyal and Abyssal (Turridae Mollusca Gastropoda). Journal of Molluscan Studies, Supplement 8:1-119.

Brocchi GB. 1814. Conchiologia fossile subappenninica con osservazioni geologiche sugli Appennini e sul suolo adiacente Vol. I: pp. LXXX + 56 + 240. Vol. II: pp. 241-712. Con 16 tavole. Milano

Brown T. 1827. Illustrations of the conchology of Great Britain and Ireland, drawn from Nature. 52 plates, D. Lizars. Edinburgh and London.

Cachia C, Mifsud C, Sammut PM. 2001. The Marine Mollusca of the Maltese Islands. Part Three. Sub-class Prosobranchia to subclass Pulmonata, order Basommatophora. Backhuys Publishers Leiden. 266 pp.

Campani E. 1999. Breve nota sul Genere Raphitoma. Documenti del Gruppo Malacologico Livornese Marzo 1999. Società Italiana di Malacologia. http://www. societaitalianadi malacologia.it/ PDF/ Campani-1999.pdf

Casey TL. 1904. Notes on the Pleurotomidae with descriptions of some new genera and species. Transactions of the Academy of Science of St Louis 14:123-170. (Not seen).

CLEMAM. (Check List of European Marine Mollusca) 2015. http://www.somali.asso.fr/clemam/index.clemam.html

Cretella M, Crovato C, Crovato P, Fasulo G, Toscano F. 2005. The malacological work of Arcangelo Scacchi 1810-1893. Part II: A Critical Review of Scacchian Taxa. Bollettino Malacologico 40:114-131.

Crosse H. 1885. Nomenclature generica e specifica di alcune Conchiglie Mediterranee, pel Marchese di Monterosato [book review]. Journal de Conchyliologie 30:139-142.

Dautzenberg P, Fischer H. 1925. Les mollusques marins du Finistère et en particulier de la région de Roscoff. Travaux de la Station Biologique de Roscoff 3:1-180.

Fedosov AE. 2008. Reduction of the alimentary system structures in predatory gastropods of the superfamily Conoidea (Gastropoda: Neogastropoda). Doklady Biological Sciences 419:136-138. doi: 10.1134/S0012496608020208

Fedosov AE. 2011. Five new species of the genus Lienardia
(Conidae: Gastropoda) from the shallow waters of central Philippines. Ruthenica 21:123-135.

Forbes E, Hanley S. 1853. A History of British Mollusca and their Shells. Vol. III. London John van Voorst. 616 pp.

Fretter V, Graham A. 1985. The Prosobranch Molluscs of Britain and Denmark. Part 8 (pp. 435-556) - Neogastropoda. Journal of Molluscan Studies Suppl. 15.

Friele H. 1874. Oversigt over de i Bergens omegn forekommende skaldækte Mollusker. Christiania Videnskabs-Selskabs Forhandlinger for 1873:1-24

Gofas S. 2015a. Trophonopsis muricata. Accessed through: World Register of Marine Species at http://www.marinespecies.org/ aphia.php? $\mathrm{p}=$ taxdetails\&id $=152370$ on 2015-02-05

Gofas S. 2015b. Raphitoma concinna. Accessed through: World Register of Marine Species at http://www.marinespecies.org/ aphia.php? $\mathrm{p}=$ taxdetails\&id=139360 on 2011-05-30

Gofas S, Moreno D, Salas C. 2011. Moluscos marinos de Andalucia. Vol. I:1-342.

Graham A. 1988. Molluscs: Prosobranch and Pyramidellid Gastropods. Synopses of the British Fauna New Series - (2 Second Edition) 1-662.

Heppell D, Smith SM, Picton BE. 1997. Mollusca, Pp. 229-268 in: Howson CM, Picton BE (editors). The Species directory of the Marine Fauna and Flora of the British Isles and Surrounding Seas.

Høisæter T. 1986. An annotated check-list of marine molluscs of the Norwegian coast and adjacent waters. Sarsia 71:73-145.

Høisæter T. 2009. Distribution of marine benthic shell bearing gastropods along the Norwegian coast. Fauna norvegica 28:5106. doi: $10.5324 /$ fn.v28i0.563

Hubendick B, Warén A. 1976. Framgälade Snäckor från Svenska Västkusten. Göteborg. 73 pp.

ICZN 1999. International code of Zoological Nomenclature. Fourth Edition. The International Trust for Zoological Nomenclature. $306 \mathrm{pp}$.

Jeffreys JG. 1847. Descriptions and Notices of British Shells. Annals and Magazine of natural History, Series 1, 19:309-314.

Jeffreys JG. 1867. British Conchology. Vol. IV. London: John van Voorst. 486 pp.

Kantor YuI, Sysoev AV. 1986. A new genus and new species from the family Turridae (Gastropoda, Toxoglossa) in the northern part of the Pacific Ocean. Zoologichesky Zhurnal 65:485-498. (In Russian, not seen).

Kilburn RN. 2009. Genus Kermia (Mollusca: Gastropoda: Conoidea: Conidae: Raphitominae) in South African Waters, with observations on the identities of related extralimital species. African Invertebrates 50, 217-236. doi: 10.5733/afin.050.0201

Locard A. 1892. Les Coquilles Marines des Côtes de France. Baillière Paris. 384 pp. (Not seen).

Marshall JT. 1912. Additions to "British conchology". Part VII. Journal of Conchology 13:294-306.

Michaud ALG. 1828. Description de plusieurs espèces de coquilles vivantes de la Méditerranée. Bulletin d'Histoire Naturelle de la Société Linnéenne de Bordeaux 210:119-122, one plate.

Montagu G. 1803. Testacea Britannica or natural history of British Shells. Part I. J. White, London. 606 pp.

Monterosato T di. 1872. Notizie intorno alle conchiglie fossili di Monte Pellegrino e Ficarazzi. Palermo. 44 pp.

Monterosato T di. 1884. Nomenclatura generica e specifica di 
alcune Conchiglie Mediterranee. Virzi Palermo. $152 \mathrm{pp}$.

Morassi M, Bonfitto A. 2010. New raphitomine gastropods (Gastropoda: Conidae: Raphitominae) from the South-West Pacific Zootaxa 2526:54-68.

Nekhaev IO. 2014. Marine shell-bearing Gastropoda of Murman (Barents Sea): an annotated check-list. Ruthenica 24:75-121.

Nordsieck F. 1977. The Turridae of the European seas. La Piramide, Roma. 131 pp. (Not seen).

Norman AM. 1879. The mollusca of the fiords near Bergen Norway. Journal of Conchology 2:8-77.

Olivera BM, Hillyard DR, Watkins M. 2008. A new species of Gemmula Weinkauff 1875; Evidence of two clades of Philippine species in the genus Gemmula. Philippine Science Letters $11: 11-15$.

Oliverio M. 1995. The systematics of the radula-less gastropod Clathromangelia (Caenogastropoda, Conoidea). Zoologica Scripta 24:193-201.

Oliverio M. 1996. Contrasting developmental strategies and speciation in N.E. Atlantic Prosobranchs: a preliminary analysis. Pp. 261-266 in Taylor J. Origin and Evolutionary Radiation of the Mollusca. Oxord University Press London.

Olsen KM. 1994. On the Mollusca of the Oslofjord. Present and earlier distribution with notes on changes in the fauna during the last 150 years. Unpublished Cand. Scient. thesis at the Division of Zoology. The University of Oslo.

Öztürk B., Buzzurro G, Avni Benli H. 2004. Marine molluscs from Cyprus: new data and checklist. Bollettino Malacologico 39:49-78.

Pinna G. 1971. I tipi delle specie di Gasteropodi terziari istituite da Giuseppe de Cristofori e Giorgio Jan nel 1832 conservati nelle collezioni del Museo Civico di Storia Naturale di Milano. Atti soc. Ital. Sci. Nat. Museo civico di Storia Naturale di Milano 112:421-440.

Pinna G, Spezia L. 1978. Catalogo dei tipi del Museo civico di Storia Naturale di Milano 5. I tipi dei gasteropodi fossili. Atti soc. Ital. Sci. Nat. Museo civico di Storia Naturale di Milano 119:125-180 pls 5-68.

Ponder WF, Warén A. 1988. Classification of the Caenogastropoda and Heterostropha - a list of the family-group names and higher taxa. Malacological Review, Supplement 4:288-326.

Powell AWB. 1966. The Molluscan Families Speightidae and Turridae. Bulletin of the Auckland Institute and Museum 5.184 pp, 21 plates.

Puillandre N, Baylac M, Boisselier MC, Cruaud C, Samadi S. 2009. An integrative approach to species delimitation in Benthomangelia (Mollusca: Conoidea). Biological Journal of the Linnean Society 96:696-708. doi: 10.1111/j.10958312.2008.01143.x

Puillandre N, Cruaud C, Kantor Y. 2010. Cryptic species in Gemmuloborsonia Gastropoda: Conoidea). Journal of Molluscan Studies 76:11-23. doi: 10.1093/mollus/eyp042

Puillandre N, Duda TF, Meyer C, Olivera BM, Bouchet P. 2015. One, four or 100 genera? A new classification of the cone snails. Journal of Molluscan Studies 81: 1-23. doi: 10.1093/mollus/ eyu055

Puillandre N, Kantor Y, Sysoev A, Couloux A, Meyer C, Rawlings T, Todd J, Bouchet P. 2011. The dragon tamed? A molecular phylogeny of the Conoidea (Mollusca Gastropoda). Journal of Molluscan Studies 77:259-272. doi: 10.1093/mollus/eyr015
Puillandre N, Samadi S, Boisselier MC, Sysoev AV, Kantor YI, Cruaud C, Couloux A, Bouchet P. 2008. Starting to unravel the toxoglossan knot: Molecular phylogeny of the "turrids" (Neogastropoda: Conoidea). Molecular Phylogenetics and Evolution 47:1122-1134. doi: 10.1016/j.ympev.2007.11.007

Pusateri F, Giannuzzi-Savelli R, Oliverio M. 2012. A revision of the Mediterranean Raphitomidae 1: On the sibling species Raphitoma contigua Monterosato 1884 and Raphitoma spadiata n.sp. (Gastropoda Conoidea). Iberus 30:41-52.

Pusateri F, Giannuzzi-Savelli R, Oliverio M. 2013. A revision of the Mediterranean Raphitomidae 2: On the sibling species Raphitoma lineolata B.D.D. 1883) and Raphitoma smriglio n.sp. (Gastropoda Conoidea). Iberus 31:11-20.

Rodriguez Babio C, Thiriot-Quiévreux C. 1974. Gastéropodes de la région de Roscoff. Étude particulière de la protoconque. Cahiers de Biologie Marine 15:534-549.

Rolán E. 1983. Moluscos de la Ria de Vigo. I - Gasteropodos. Thalassas 1 Anexo 1:1-383.

Rolán E. 2005. Malacological Fauna from the Cape Verde Archipelago. Part I Polyplacophora and Gastropoda. Conch Books. 455 pp.

Rolán E, Otero-Schmitt J, Fernandes F. 1998. The Family Turridae s.l. in Angola West Africa) 1. Subfamily Daphnellinae. Iberus 16 (1):95-118.

Sabelli B, Giannuzzi-Savelli R, Bedulli F. 1990. Annotated CheckList of Mediterranean Marine Mollusks Volume 1. Libreria Naturalistica Bolognese Bologna. 348 pp.

Sars GO. 1878. Bidrag til Kundskaben om Norges arktiske Fauna. I. Mollusca Regionis Arcticae Norvegiae. Oversigt over de i Norges arktiske region forekommende bløddyr. Universitetsprogram for første halvaar 1878. Christiania. 466 pp.

Scacchi A. 1836. Catalogus Conchyliorum Regni Neapolitani quae usque adhuc reperit A. Scacchi. Typis Filiatre-Sebetii, Neapoli, 18 pp., 1 pl. (Not seen).

Seaward DP. 1990. Distribution of the marine molluscs of north west Europe. Nature Conservancy Council Peterborough. 114 pp.

Sheridan R, Van Mol JJ, Bouillon J. 1973. Étude morphologique du tube digestif de quelques Turridae Mollusca - Gastropoda Prosobranchia - Toxoglossa) de la région de Roscoff. Cahiers de Biologie Marine 14:159-188.

Smith EH. 1967a. Two new species of British Turrids. The Veliger $10: 1-4$

Smith EH. 1967b. The proboscis and oesophagus of some British turrids. Transactions of the Royal Society of Edinburgh 67:1-22.

Smith J. 1839. On the last changes in the relative levels of the land and sea in the British Islands. Memoirs of the Wernerian Natural History Society (Edinburgh) 8:49-113. (Not seen).

Smith SM, Heppell D. 1991. Checklist of British Marine Mollusca. National Museums of Scotland Information Series 11:1-114.

Spada G. 2008. Family Conidae in: Oliverio M. 2008. Gastropoda Prosobranchia in: Relini G.ed. Checklist della flora e della fauna dei mari italiani. Biologia Marina Mediterranea 15 (suppl):235278.

Taylor JD, Kantor Y, Sysoev A. 1993. Foregut anatomy feeding mechanisms relationships and classification of the Conoidea $=$ Toxoglossa (Gastropoda). Bulletin of the natural History Museum of London Zoology Series) 59:125-170. 
Thiele J. 1929. Handbuch der systematischen Weichtierkunde. I.G. Fischer, Stuttgart. $778 \mathrm{pp}$.

Warén A. 1980. Marine Mollusca described by John Gwyn Jeffreys with the location of type material. Conchological Society of Great Britain and Ireland. Special Publication 1:1-60, 8 plates.

WORMS 2015. Etrema rubroapicata (E.A. Smith, 1882). Accessed through: World Register of Marine Species at http://www. marinespecies.org/aphia.php?p=taxdetails\&id=433666 on 201501-21.

Editorial responsibility: Torkild Bakken.

This article is open-access and distributed under the terms of the Creative Commons Attribution 4.0 International license. This permits all non-commercial use, distribution, and reproduction in any medium, provided the original work is properly cited.

(http://creativecommons.org/licenses/by/4.0/). 